Article

\title{
Future Simulation of Land Use Changes in Rapidly Urbanizing South China Based on Land Change Modeler and Remote Sensing Data
}

\author{
Sarah Hasan ${ }^{1}{ }^{1}$, Wenzhong Shi ${ }^{1, *}$, Xiaolin Zhu ${ }^{1}$, Sawaid Abbas ${ }^{1, *}$ (I) and \\ Hafiz Usman Ahmed Khan ${ }^{2}$ \\ 1 Department of Land Surveying and Geo-Informatics, The Hong Kong Polytechnic University, \\ Kowloon, Hong Kong; sarah.hasan@connect.polyu.hk (S.H.); xiaolin.zhu@polyu.hk (X.Z.) \\ 2 Department of Space Technology Application, Beihang University, Beijing 100000, China; \\ hafiz_usmankhan@hotmail.com \\ * Correspondence: lswzshi@polyu.edu.hk (W.S.); sawaid.abbas@gmail.com (S.A.); Tel.: +852-2766-5975 (W.S.)
}

Received: 30 March 2020; Accepted: 21 May 2020; Published: 26 May 2020

check for updates

\begin{abstract}
Landscape transformations in rapidly urbanizing Guangdong, Hong Kong, and Macao (GHKM) regions of South China represent the most complex and dynamic processes altering the local ecology and environment. In this study, Land Change Modeler (LCM) is applied to land use land cover (LULC) maps for the years 2005, 2010, and 2017, derived from Landsat images, with the aim of understanding land use land cover change patterns during 2005-2017 and, further, to predict the future scenario of the years 2024 and 2031. Furthermore, the changes in spatial structural patterns are quantified and analyzed using selected landscape morphological metrics. The results show that the urban area has increased at an annual rate of 4.72\% during 2005-2017 and will continue to rise from $10.31 \%\left(20,228.95 \mathrm{~km}^{2}\right)$ in 2017 to $16.30 \%\left(31,994.55 \mathrm{~km}^{2}\right)$ in 2031 . This increase in urban area will encroach further into farmland and fishponds. However, forest cover will continue to increase from $45.02 \%\left(88,391.98 \mathrm{~km}^{2}\right)$ in 2017 to $46.88 \%\left(92,049.62 \mathrm{~km}^{2}\right)$ in 2031 . This implies a decrease in the mean Euclidian nearest neighbor distance (ENN_MN) of forest patches (from $217.57 \mathrm{~m}$ to $206.46 \mathrm{~m}$ ) and urban clusters (from $285.55 \mathrm{~m}$ to $245.06 \mathrm{~m}$ ) during 2017-2031, indicating an accelerated landscape transformation if the current patterns of the change continues over the next decade. Thus, knowledge of the current and predicted LULC changes will help policy and decision makers to reconsider and develop new policies for the sustainable development and protection of natural resources.
\end{abstract}

Keywords: land use land cover; land change modeler; prediction; Guangdong; Hong Kong; Macao; Landsat

\section{Introduction}

Today, urban growth represents powerful engines for economic prosperity and growth. However, changes in land use land cover (LULC) are pervasive and subjects of great concern worldwide [1]. This is more pronounced in rapidly growing countries, such as China [2], where urban land transactions and local land leasing revenue have exploded sharply [3], after the opening of the economic corridor policy in 1978. The phenomena of socioeconomic development and industrialization have resulted in an increasing urban population, rural to urban migration, reclassification of administrative rural zones to urban zones, and subsequent expansion of urban areas and cities in peri-urban pockets, at unparalleled rates [2,4-6]. According to the United Nations Department of Economic and Social Affairs Population Division (2017), China's total urban population has increased from $11.80 \%(7726(10,000$ persons)) in 1950 to $58.52 \%$ (139,008 (10,000 persons)) in 2017 , and is predicted to reach $76.10 \%$ by the end of 2050 [7]. This situation has simultaneously strengthened economic localism, as built land 
produces more revenue [3]. However, these significant changes cause continuous stress on agricultural land and other natural and semi natural resources [8-10].

In China, the fragmentation of farmland into urban fringe and loss of other natural and semi natural resources have a strong prospective of weakening an enduring coherence of human beings and their environment, as well as a serious threat to food security [11]. Immense anthropogenic activities have generated many ecological and environmental issues on different spatial scales, resulting in the increased scarcity of land resources. These include unplanned land development, employment opportunities, the escalation of slums, and insufficient infrastructure and houses [1,2,8,12-14]. The prevailing high dynamic economic growth, urbanization, and industrialization have posed a great challenge to policy and decision makers to achieve the goal of sustainable development $[2,6,8,15,16]$. Therefore, the modeling and future prediction of land use land cover and urban growth is a pressing need to enable comprehensive view regarding a more competent administration of urban planning, preservation of natural resources (such as farmland), and the espousal of long-term sustainable policies.

Recently, to better understand the functioning of the land use system, the modeling of land use land cover change has grown rapidly in the spatially explicit scientific field [16,17]. Land change models are simplifications of reality that offers an important means of predicting future land use land cover change pressure points $[18,19]$ and develop ex-ante visions of urbanization process implications [1]. Models usefully simplify the complex suite of socioeconomic and biophysical forces that influence the rate and spatial patterns of land use land cover change and enable the estimation of the impacts of changes in land use land cover [17,20-24]. To date, a variety of models have been developed, and are classified into the following types: (1) machine learning model, (2) cellular based model, (3) spatial based model, (4) agent based approaches [10,18,20,25,26], and (5) hybrid approaches [27]. The performance of different modelling tools, however, is difficult to compare because land use land cover change models can be fundamentally different in a variety of ways $[16,28,29]$. Several studies have revealed that Land Change Modeler (LCM), based on integrated multilayer perceptron (MLP) with Markov chain (MC), is a strong model for the analysis and prediction of land use land cover change, urban growth, and the validation of results $[8,16,20,26,30,31]$. This is because outputs of neural networks, acquired through the weights of evidence technique (where a user can select and modify the weights) $[20,32,33]$, more effectively show the transition of different types of land cover than do individual probabilities.

Landscape morphological and structural metrics are also used to directly compute the structure, spatio-temporal patterns of urban change, and land use land cover change from the thematic maps. The metrics, however, provide a better illustration and explanation of spatial heterogeneity at a particular resolution and scale. They may give a connection among the physical structure of a landscape and urban pattern, shape, functionality, and process [34-36]. These simple quantitative indices, i.e., landscape metrics have also been used to interpret, asses, and verify urban models [6,10,37-42]. Herold et al. (2003) applied landscape metrics and an urban growth model in Santa Barbara, California from 1930 to 2001 and predicted the urban growth to the years 2030. They concluded more compact growth around existing urban cores rather than a leapfrog of urban development [37]. Aithal et al. (2013) analyzed the land use dynamics in the rapidly urbanizing of Bangalore, India using multilayer perceptron, based on Cellular Automata (CA)-Markov and landscape metrics. Their results showed that from 2012 to 2020, urban land would expand 108\% [10]. Megahed et al. (2015) modeled the urban growth of Greater Cairo, Egypt, using landscape metrics and a land change modeler. They concluded that urbanization had accelerated from $4.64 \%$ to $17.30 \%$ during $1984-2014$ and would continue to increase to $21.93 \%$ in 2025 [20].

Guangdong, Hong Kong, and Macao (GHKM) represent one of the most significant and rapidly developing regions in China. Guangdong, Hong Kong, and Macao have undergone a transformation from a planned economy to a market oriented economy, with a fast regional economic and social development policy/strategy and urbanization acceleration process, all of which have had a significant impact on the spatial pattern of the land use land cover change $[2,18,43,44]$. The economic center of 
China, especially the Pearl River Delta (PRD) region of the Guangdong, Hong Kong, and Macao has remained the primary destination region for local and international immigrants thus, causes intense settlement [45]. The migration occurred because of the potential of remunerative job opportunities, a better education system, and other daily life facilities. This unprecedented urbanization and industrialization have caused the fragmentation of farmland into an urban fringe, with the loss of traditional farming activities and a shift in the character of rural communities [11]. Consequently, the characteristics of land use land cover in Guangdong, Hong Kong, and Macao have changed significantly. If such circumstances continue, Guangdong, Hong Kong, and Macao will then quickly become an urban slum with the least suitable living conditions for urban residents [46]. Thus, knowing the state of the future land use land cover of the Guangdong, Hong Kong, and Macao is a paramount requirement to enable the adequate design of potent urban, demographic, and economic policies and also an increase in or protection of farmland, to ensure sustainable development $[46,47]$. Therefore, the main objective of this study is to forecast future land use land cover changes, particularly urban growth, based on land change modeler. Moreover, in the detailed analysis of the land use land cover change patterns, landscape metrics were also used to decipher and analyze model predicted land cover patterns in the study area, and was further extended to the year 2031. This study also aims to provide a scientific basis for decision and policy makers to enable the development of strategies that will ensure regional ecological protection and sustainable development.

\section{Materials and Methods}

\subsection{Study Area}

The region of Guangdong, Hong Kong, and Macao is located between latitudes $20^{\circ} 13^{\prime} \mathrm{N}$ and $25^{\circ} 31^{\prime} \mathrm{N}$, and longitudes $109^{\circ} 39^{\prime} \mathrm{E}$ and $117^{\circ} 19^{\prime} \mathrm{E}$ and has an area of about $196,342 \mathrm{~km}^{2}$ (Figure 1). GHKM is situated in the southernmost part of China, and is a main economic hub of the country. The study area shared its eastern boundary with Fujian province, northern boundary with Jiangxi and Hunan provinces, western boundary with Guangxi, and a southern boundary with the South China Sea [44]. The geography of the study area is characterized by plains, plateaus, mountains, hills, and rivers. Its climate is categorized by hot, humid summers and cold, windy, dry winters. The mean annual precipitation and temperature are $1500-2000 \mathrm{~mm}$ and $22{ }^{\circ} \mathrm{C}$, respectively $[48,49]$. The availability of infrastructure has been supported by government and local authorities since the opening of the economic reform policy, 1978 and has successfully enjoyed economic prosperity. This has made Guangdong, Hong Kong, and Macao the international, cultural, and political communication center of China. This region has experienced an increase in population, socioeconomic development, and changes in land use land cover over the past three decades. The significant surge in urban area has predominantly come from the conversion of farmland into built-up areas [44]. The increase in population is mainly the result of immigration. Guangdong, Hong Kong, and Macao accommodate ever more unsatisfactory, jam-packed transportation systems, and consequent environmental pollution [11]. 


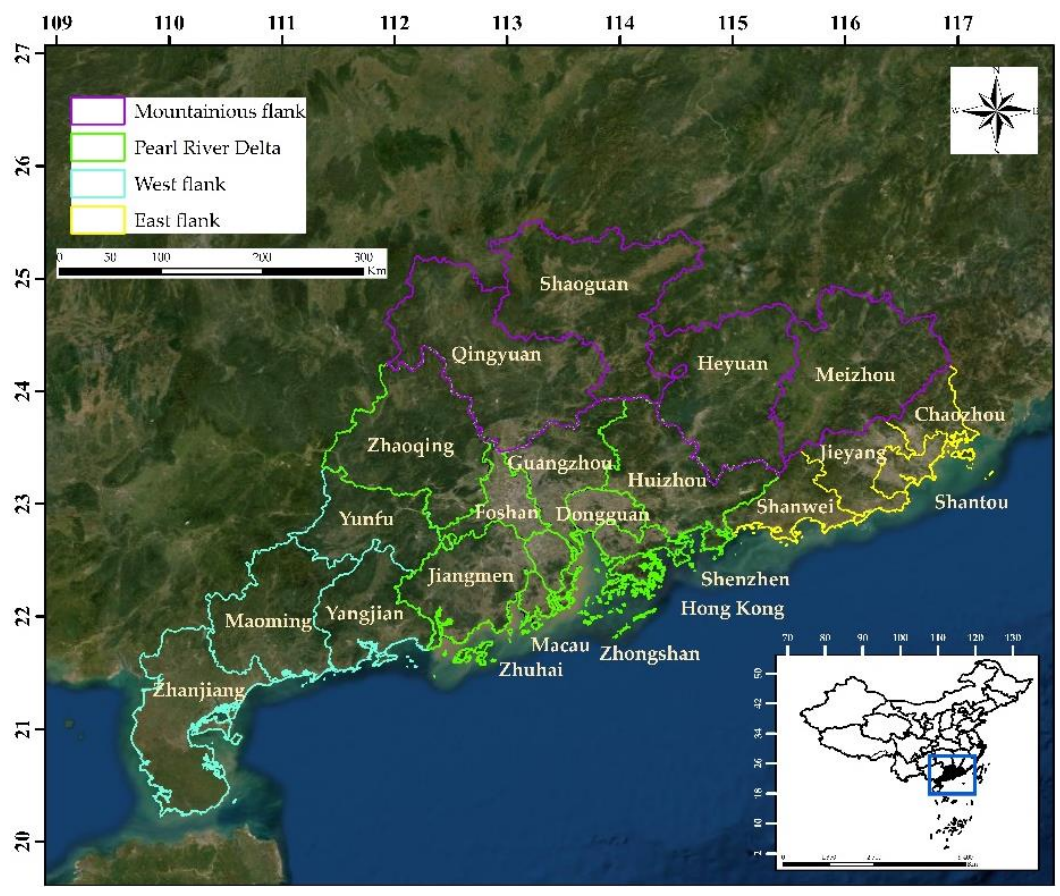

Figure 1. The geographical location of the Guangdong, Hong Kong, and Macao regions, South China.

\subsection{Data Acquisition}

The land use land cover data for the Guangdong, Hong Kong, and Macao for the years 2005, 2010, and 2017 have been produced in the author's previous study, which was based on the supervised classification of multi-temporal Landsat data (thematic mapper (TM)/enhanced thematic mapper $(\mathrm{ETM}+)$ /operational land imager (OLI)) at a $30 \mathrm{~m}$ resolution [44]. The China National Standard Land Use Classification System [50] was followed to define land use land cover classification scheme which comprises on seven classes, forest, grassland, water, fishponds, built-up, bareland, and farmland. The overall accuracy of the classified land use land cover maps is about $91 \%$ and kappa is 0.88 [44]. Other data sets include Shuttle Radar Topographic Mission (SRTM) 30 m Digital Elevation Model (DEM) downloaded from the $30 \mathrm{~m}$ SRTM Tile downloader [51], as well as road network data and water channel network data obtained from the "Open Street Map (OSM)" [52]. Slope, aspect, and hillshade were derived from the DEM. All the data were projected to a common Universal Transverse Mercator (UTM) projection, i.e., WGS-84-UTM-Zone-49N, with spatial resolution of $30 \mathrm{~m}$.

\subsection{Land Use Land Cover Change Modelling and Future Scenarios}

Land Change Modeler (LCM) in TerrSet (formerly known as IDRISI) software was originally designed to manage biodiversity influences, and to analyze and forecast land use land cover changes [23, $31,32,53,54]$. This model is based on the artificial neural network (ANN), Markov Chain matrices, and transition suitability maps, generated by training multilayer perceptron (MLP) or logistic regression [20, 26,28]. This model predicts the land use land cover changes from the thematic raster images having the same number of classes in the same sequential order [26]. In this study, the Land Change Modeler is used to forecast the future land use land cover changes in the Guangdong, Hong Kong, and Macao for the next fourteen years (for 2024 and 2031) by following four steps, namely: (1) change analysis, (2) transition potential and determination of explanatory variables, (3) change prediction, and (4) model validation $[20,55]$. 


\subsubsection{Change Analysis}

In the change analysis panel, the changes between two different time periods time 1 and time 2 land use land cover maps were calculated. The change analysis provides a quick evaluation of quantitative change, by charting gains and losses, among different land cover types [31]. It also estimates net change, persistence, and the specific transition of land cover information both in map and geographical forms [53]. These changes are important to identify the dominant transition from one class to another, all the dominant transitions are then grouped and targeted [20,55]. The spatial trend of change provides the trend in the form of a map, with the best fit polynomial trend surface adhering to the pattern of change [53].

\subsubsection{Transition Potential Modeling and Driving Forces Determination}

\section{Transition Potential}

The transition potential determines the area of change [20]. Land cover transitions can be grouped into sub-models, if it is assumed that for each transition, the underlying drivers of change are the same [33]. For example, the processes that influence the land use land cover to change from farmland to built-up land may be the same as those that affect the change of forest to built-up land. Thus, land use land cover changes with common driving variables were grouped into sub-models [54]. In addition, evidence likelihood was selected to determine the relative frequency of different land use land cover types which had occurred within the transitional areas [20].

\section{Selection of Explanatory Variables}

Explanatory variables or drivers, responsible for land use land cover change, were selected on the basis of factors that increase or decrease the appropriateness of a specific alternative for the activity of concern $[8,31]$. Topography represents a significant factor for urban change. Topography influences the city size and its spatial distribution, by possible restraints of water supply and provision of adequate land [56]. In general, the slope, aspect, and elevation are recognized as the most imperative topographic factors affecting urban sprawl $[45,57,58]$. Proximity factors such as distance to water channels and distance to roads also play an imperative role in urban sprawl, as each provide convenience to dwellers to access resources and everyday needs. Neighborhood effects generally show that, in a non-built-up pixel surrounded by built-up land, it is more likely to eventually to transform into a built-up area. As regards land use land cover planning and policy, factors differ because of the different institutional contexts of the different study areas. For example, in this study area (GHKM), urban development can be influenced by different planning guidelines and regulations, including master plans and zoning $[8,30,31]$. In this study, both topographic and proximity factors were selected to scrutinize the urbanization and land use land cover change impacts. These variables are expected to have a significant influence on future changes [54,59]. The significance of each variable is tested using Cramer's V, a quantitative measure $[53,54]$. However, Cramer's V does not assure a strong performance of the variables, since it cannot represent the scientific prerequisites and the multifaceted nature of the relationships. It simply helps to determine whether or not to include the particular variable as a driving factor of land use land cover change $[16,20,60]$.

\section{Multilayer Perceptron (MLP)}

The multilayer perceptron (MLP) neural network is a feedforward neural network with one or more layers between the input and output layers. MLP depends on the back propagation (BP) algorithm that is a supervised training algorithm $[31,61,62]$. It plays a central role in the land change modeler, and consists of three layers, namely (1) input, (2) hidden, and (3) output [31]. Through feed-forward algorithms, networks calculate weights for input values, input layer nodes, hidden layer nodes, and output layer nodes, all of which propagate through the hidden layer, (set of computational nodes) to output layers. For modeling, the multilayer perceptron allows more than one transition at 
a time $[20,60]$. In multilayer perceptron, through hidden layers, the data flows in one direction, from an input layer to an output layer and determines non-linear relationships. Within the layers, the nodes are assembled, and every node receives an input signal from the different nodes and yields a transformed signal to other nodes. After assigning a weight to each original input layer, which includes a threshold, it passes through either a linear or non-linear stimulation function. To reduce the error between the observed and the expected results, the weights must be resolved in the training process, before the system can be utilized for forecast purposes [20,60]. After the multilayer perceptron has been trained with various influencing factors [26] for each of the sub-models, it produces time-explicit transition potential maps that represent time-explicit change potential $[2,27,54,62]$.

\subsubsection{Change Prediction}

Change prediction is the last step in which the future prediction is executed on the basis of Markov chain, and using the historical rate of change and the transition potential maps [55].

\section{Markov Change Model}

The Markov chain model, is a stochastic modelling procedure, extensively used for land use land cover change modelling. This model forecasts the future land use land cover from time $t=1$ to another time $t+1$ [63], on the basis of the transition probability matrix and the transition area matrix of each land use land cover class [47]. The transition matrix represents the probability of land use land cover change in the observed time period from one land use group to another $[18,64,65]$. Transition probability maps, generated through multilayer perceptron, provide a probability estimation that each pixel will either be converted into another land cover type or persist be adjusted during annual time steps [54].

\subsubsection{Future Scenario}

Land Change Modeler produces two kinds of predictions: (1) hard prediction and (2) soft predictions. A hard prediction produces a predicted map, [20] based on a multi-objective land allocation (MOLA) module [54]. One of the land cover classes is assigned to each pixel, on the basis of their most likely probability. Soft prediction determines the probability of the pixel changing to another land category by producing a vulnerability map, where the value from $0-1$ is assigned to each pixel [20].

\subsubsection{Model Validation}

Model validation is needed to assess the accuracy. Thus, the objective of the validation process is to determine the quality of 2017's simulated map in comparison with 2017's actual land use land cover map. For model validation, there are two well recognized methods: (1) Kappa statistics and (2) relative operating characteristics (ROC) $[31,66]$. Kappa statistics is a quantitative method that measures the goodness of fit or the best value between the model prediction and the observed maps, revised for precision by possibility in the form of $\mathrm{K}$ no (overall accuracy), kappa location (kappa for grid cell level location), K location Strata (kappa location strata), and K standard (kappa standard). The range of Kappa values is from 1 to -1 , where positive values show, by chance, an unusually greater improved agreement, and negative values are a bad agreement [6,29,32,66,67]. Kappa values were categorized as poor below 0.40 , fair to good from 0.40 to 0.75 , and excellent over 0.75 [32]. Relative operating characteristics, however, are well able to compare a Boolean map of "reality" with a suitability map. ROC is defined as a graph between the rate of true positives on the vertical axis and the rate of false positives on the horizontal axis. Its value ranges between 0 and 1 , where, 1 shows a perfect fit and 0.5 shows a random fit $[24,26,29,53,68]$. The threshold value for the relative operating characteristics used in this study is 100. If the assessment of the simulation yields valid results [30,69], the calibrated model with the same driving forces then predicts the 2024 and 2031 land use land cover map, modelling the changes between 2005 and 2017 land use land cover maps. 


\subsection{Landscape Metrics}

Landscape metrics are used to illustrate and compute the spatial characteristics of patches, land use land cover class area, and the whole land cover over time. This is useful for monitoring, measuring, and analyzing land use land cover change, such as changes in urban sprawl and its structure [70]. They illustrate significant landscape information, such as the composition and configuration, heterogeneity, diversity, compactness, fractal dimensions, linearity and squareness, complexity, fragmentation, and morphological characteristics. However, their selection, interpretation, analysis, and evaluation depend on the specific study context, classified map, and the inherent process of change $[6,10,20,37,41,71]$. The matrices used for this study are listed in Table 1 , and are based on similar studies [6,20,37,39,42,70-79]. These metrics were computed using the FRAGSTATS software [80] based on land use land cover maps for the years 2005, 2010, 2017, and predicted 2024 and 2031.

Table 1. The description of landscape metrics used for morphological analysis (where, CL = class level, $\mathrm{LL}=$ landscape level).

\begin{tabular}{|c|c|c|c|c|c|}
\hline Category & Metric Name & $\begin{array}{c}\text { Acronym } \\
\text { Unit }\end{array}$ & $\begin{array}{l}\text { Level } \\
\text { Used }\end{array}$ & Description & Range \\
\hline \multirow{3}{*}{$\begin{array}{l}\text { Patch Size } \\
\text { and Density }\end{array}$} & $\begin{array}{l}\text { Patch Density } \\
\text { (PD) }\end{array}$ & $\begin{array}{l}\text { Number of } \\
\text { patches per } \\
100 \text { ha }\end{array}$ & CL & $\begin{array}{l}\text { The number of patches per unit } \\
\text { area }\end{array}$ & $\begin{array}{l}\mathrm{PD} \geq 1, \text { no } \\
\text { limit }\end{array}$ \\
\hline & $\begin{array}{l}\text { Percentage of } \\
\text { Landscape } \\
\text { (PLAND) }\end{array}$ & $\%$ & CL & The aggregated area of landscape. & $0-100$ \\
\hline & $\begin{array}{l}\text { Mean Patch Area } \\
\text { (MPA) }\end{array}$ & ha & CL & An average patch size in each class & $\begin{array}{l}\text { MPA }>0 \\
\text { no limit }\end{array}$ \\
\hline \multirow{3}{*}{$\begin{array}{l}\text { Shape and } \\
\text { Edge }\end{array}$} & $\begin{array}{l}\text { Edge Density } \\
\text { (ED) }\end{array}$ & $\mathrm{m} / \mathrm{ha}$ & CL & $\begin{array}{l}\text { Calculate the total lengths of all } \\
\text { edge segments of corresponding } \\
\text { patch type per unit area. Edge } \\
\text { density explained the complexity } \\
\text { of each patch shape. }\end{array}$ & $\begin{array}{l}\mathrm{ED} \geq 1, \text { no } \\
\quad \text { limit }\end{array}$ \\
\hline & $\begin{array}{l}\text { Largest Patch } \\
\text { Index (LPI) }\end{array}$ & $\%$ & CL & $\begin{array}{l}\text { Ratio between the largest patch of } \\
\text { the corresponding patch type and } \\
\text { the total landscape area. }\end{array}$ & $\begin{array}{l}0<\mathrm{LPI} \leq \\
100\end{array}$ \\
\hline & $\begin{array}{l}\text { Area Weighted } \\
\text { Mean Fractal } \\
\text { Dimension Index } \\
\text { (AWMPFD) }\end{array}$ & None & LL & $\begin{array}{l}\text { Measure the average fractal } \\
\text { dimensions of patches of } \\
\text { a particulate patch type divided } \\
\text { by the total sum of the patch area. }\end{array}$ & $\begin{array}{l}1 \leq \\
\text { AWMPFD } \\
\quad \leq 2\end{array}$ \\
\hline Proximity & $\begin{array}{l}\text { Mean Euclidean } \\
\text { Nearest } \\
\text { Neighbor } \\
\text { Distance } \\
\text { (ENN_MN) }\end{array}$ & $\mathrm{m}$ & CL & $\begin{array}{l}\text { Measure the minimum edge to } \\
\text { edge distance to the nearest } \\
\text { neighbor same patch type. It } \\
\text { explains isolation of } \\
\text { corresponding patch type or } \\
\text { landscape. }\end{array}$ & $\underset{0}{\text { ENN_MN }>}$ \\
\hline \multirow{2}{*}{$\begin{array}{l}\text { Diversity } \\
\text { and Texture }\end{array}$} & $\begin{array}{l}\text { Contagion } \\
\text { (CONTAG) }\end{array}$ & $\%$ & LL & $\begin{array}{l}\text { Measure the total probability that } \\
\text { a patch of cells neighboring } \\
\text { the same type of cells. }\end{array}$ & $\begin{array}{c}0< \\
\text { CONTAG } \leq \\
100\end{array}$ \\
\hline & $\begin{array}{l}\text { Shannon's } \\
\text { Diversity Index }\end{array}$ & None & LL & $\begin{array}{l}\text { Indicate diversity in a landscape } \\
\text { from the abundance of patch } \\
\text { types. It increases as the number } \\
\text { of different patch types increases } \\
\text { or the distribution of area/land } \\
\text { among patch types/classes } \\
\text { becomes more equitable. }\end{array}$ & $\begin{array}{l}\text { Shannon's } \\
\text { Entropy } \geq 0 \\
\text { no limit }\end{array}$ \\
\hline
\end{tabular}




\section{Results}

\subsection{Land Cover Change Analysis}

The land use land cover maps for the years 2005, 2010, and 2017 [44] are shown in Figure 2. The area statistics of different land use land cover categories between different years are shown in Table 2 . During 2005-2017, the built-up area increased from 5.84\% $\left(11,475.77 \mathrm{~km}^{2}\right)$ to $10.31 \%\left(20,228.95 \mathrm{~km}^{2}\right)$, with a significant annual rate of change of $4.72 \%$. The growth of built-up area is different in different periods, i.e., 2.41\% during 2005-2010 (period 1) and 2.06\% during 2010-2017 (period 2). This significant rise in built-up area has resulted in a decline in both farmland and fishponds. Farmland covered an area of $40.77 \%\left(80,043.82 \mathrm{~km}^{2}\right)$ in 2005 but decreased substantially to $37.63 \%\left(73,890.27 \mathrm{~km}^{2}\right)$ in 2010 and $33.03 \%\left(64,938.68 \mathrm{~km}^{2}\right)$ in 2017, respectively. Thus, farmland declined by $3.13 \%$ during $2005-2010$, $4.60 \%$ in $2010-2017$, and $7.73 \%$ in $2005-2017$. Similarly, fishponds decreased from $1.56 \%\left(3059.93 \mathrm{~km}^{2}\right)$ in 2005 to $0.97 \%\left(1902.79 \mathrm{~km}^{2}\right)$ in 2017 , with a significant change of $3.96 \%\left(1157.13 \mathrm{~km}^{2}\right)$. Furthermore, as a result of different afforestation programs, forest cover increased from $40.84 \%\left(80,180.31 \mathrm{~km}^{2}\right)$ in 2005 to $42.39 \%\left(83,223.94 \mathrm{~km}^{2}\right)$ in 2010 and $45.02 \%\left(88,390.98 \mathrm{~km}^{2}\right)$ in 2017, respectively (Table 2).

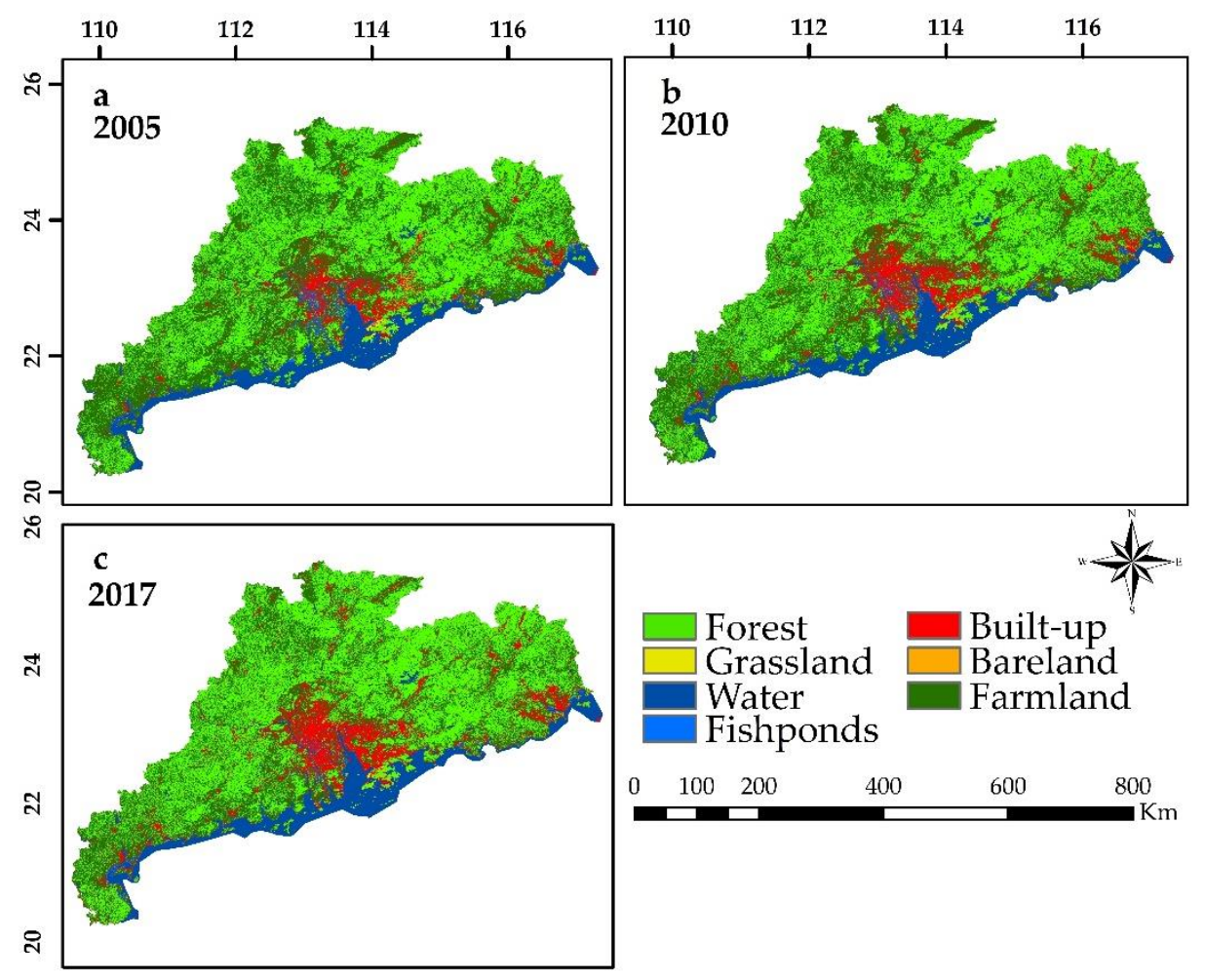

Figure 2. The land use land cover map for the years 2005, 2010, and 2017 of the Guangdong, Hong Kong, and Macao.

Table 2. Area statistics of the land use land cover classes for the years 2005, 2010, and 2017.

\begin{tabular}{|c|c|c|c|c|c|c|c|c|c|c|c|c|}
\hline Year & 2005 & & 2010 & & 2017 & & $\begin{array}{l}\text { Change } \\
\text { 2005-2010 }\end{array}$ & Change & $\begin{array}{l}\text { Change } \\
2010-2017\end{array}$ & Change & $\begin{array}{l}\text { Change } \\
\text { 2005-2017 }\end{array}$ & Change \\
\hline Classes & $\mathrm{km}^{2}$ & $\%$ & $\mathrm{~km}^{2}$ & $\%$ & $\mathrm{~km}^{2}$ & $\%$ & $\mathrm{~km}^{2}$ & $\%$ & $\mathrm{~km}^{2}$ & $\%$ & $\mathrm{~km}^{2}$ & $\%$ \\
\hline Forest & $80,180.31$ & 40.84 & $83,223.94$ & 42.39 & $88,391.98$ & 45.02 & 3043.63 & 1.55 & 5168.03 & 2.58 & 8211.67 & 4.13 \\
\hline Grassland & 399.84 & 0.20 & 143.26 & 0.07 & 189.47 & 0.10 & -256.58 & -0.13 & 46.21 & 0.02 & -210.37 & -0.11 \\
\hline Water & $20,249.86$ & 10.31 & $20,211.49$ & 10.29 & $20,656.34$ & 10.51 & -38.37 & -0.02 & 444.84 & 0.21 & 406.47 & 0.19 \\
\hline Fishponds & 3059.93 & 1.56 & 2453.32 & 1.25 & 1902.79 & 0.97 & -606.61 & -0.31 & -550.53 & -0.28 & -1157.14 & -0.59 \\
\hline Built-up & $11,475.77$ & 5.84 & $16,203.51$ & 8.25 & $20,228.95$ & 10.31 & 4727.74 & 2.41 & 4025.44 & 2.06 & 8753.18 & 4.45 \\
\hline Bareland & 934.47 & 0.48 & 218.44 & 0.11 & 275.21 & 0.14 & -716.03 & -0.36 & 56.77 & 0.03 & -659.26 & -0.34 \\
\hline Farmland & $80,043.82$ & 40.77 & $73,890.27$ & 37.63 & $64,938.68$ & 33.03 & -6153.55 & -3.13 & -8951.59 & -4.60 & $-15,105.14$ & -7.73 \\
\hline
\end{tabular}


The gains and losses of different land use land cover thematic classes were calculated, as shown in Table 3. Major land use land cover changes include (1) expansion of built-up land, (2) reduction in farmland and fishponds, and (3) increase in forest cover. During 2005-2017, gain and loss in forest cover was $10,092.25 \mathrm{~km}^{2}(2.09 \%)$ and $1880.78 \mathrm{~km}^{2}(-0.39 \%)$, with a net gain of $8211.47 \mathrm{~km}^{2}(1.70 \%)$. Fishponds loss $2276.21 \mathrm{~km}^{2}(-0.47 \%)$ and gained $880.06 \mathrm{~km}^{2}(0.18 \%)$, with a net loss of $1396.15 \mathrm{~km}^{2}(-0.29 \%)$. Farmland lost $15,672.26 \mathrm{~km}^{2}(-3.25 \%)$ and gained $566.94 \mathrm{~km}^{2}(0.12 \%)$ with a net loss of $15,105.30 \mathrm{~km}^{2}$ $(-3.13 \%)$. Built-up land, however, increased with a net gain of $8753.13 \mathrm{~km}^{2}(1.81 \%)$. During the same period, the classes that contributed to the net change of built-up area are listed as: forest $1067.32 \mathrm{~km}^{2}$ $(0.22 \%)$, grassland $47.42 \mathrm{~km}^{2}(0.01 \%)$, water $272.06 \mathrm{~km}^{2}(0.06 \%)$, fishponds $867.93 \mathrm{~km}^{2}(0.18 \%)$, bareland $346.48 \mathrm{~km}^{2}$, and farmland $6151.92 \mathrm{~km}^{2}(0.07 \%)$ were transformed to built-up area. The contribution to the net change of other classes are shown in Table 3. In summary, the reduction in farmland concurs with the expansion of radioactivity aligned to the urbanization growth.

Table 3. Land use land cover gains, losses, and contributions to net change in each category during 2005-2010, 2010-2017, and 2005-2017.

\begin{tabular}{|c|c|c|c|c|c|c|c|c|c|}
\hline \multicolumn{10}{|l|}{ 2005-2010 } \\
\hline \multirow{2}{*}{ Classes } & \multirow[t]{2}{*}{ Gain } & \multirow[t]{2}{*}{ Loss } & \multicolumn{7}{|c|}{ Net Contribution } \\
\hline & & & Forest & Grassland & Water & Fishponds & Built-Up & Bareland & Farmland \\
\hline & $\%$ & $\%$ & $\%$ & $\%$ & $\%$ & $\%$ & $\%$ & $\%$ & $\%$ \\
\hline Forest & 0.88 & 0.25 & 0.00 & -0.02 & 0.00 & 0.00 & 0.12 & 0.00 & -0.73 \\
\hline Grassland & 0.01 & 0.06 & 0.02 & 0.00 & 0.00 & 0.01 & 0.00 & 0.00 & 0.02 \\
\hline Water & 0.18 & 0.19 & 0.00 & 0.00 & 0.00 & -0.01 & 0.02 & 0.00 & -0.01 \\
\hline Fishponds & 0.23 & 0.36 & 0.00 & -0.01 & 0.01 & 0.00 & 0.11 & 0.00 & 0.01 \\
\hline Built-Up & 0.98 & 0.00 & -0.12 & 0.00 & -0.02 & -0.11 & 0.00 & -0.06 & -0.67 \\
\hline Bareland & 0.03 & 0.18 & 0.00 & 0.00 & 0.00 & 0.00 & 0.06 & 0.00 & 0.09 \\
\hline Farmland & 0.21 & 1.48 & 0.73 & -0.02 & 0.01 & -0.01 & 0.67 & -0.09 & 0.00 \\
\hline \multicolumn{10}{|l|}{ 2010-2017 } \\
\hline Forest & 1.39 & 0.32 & 0.00 & 0.00 & 0.04 & -0.02 & 0.14 & 0.02 & -1.24 \\
\hline Grassland & 0.03 & 0.02 & 0.00 & 0.00 & 0.00 & 0.00 & 0.00 & 0.00 & -0.01 \\
\hline Water & 0.27 & 0.18 & -0.04 & 0.00 & 0.00 & -0.07 & 0.04 & 0.00 & -0.02 \\
\hline Fishponds & 0.18 & 0.35 & 0.02 & 0.00 & 0.07 & 0.00 & 0.06 & 0.00 & 0.01 \\
\hline Built-up & 0.83 & 0.00 & -0.14 & 0.00 & -0.04 & -0.06 & 0.00 & -0.01 & -0.59 \\
\hline Bareland & 0.05 & 0.04 & -0.02 & 0.00 & 0.00 & 0.00 & 0.01 & 0.00 & -0.01 \\
\hline Farmland & 0.07 & 1.92 & 1.24 & 0.01 & 0.02 & -0.01 & 0.59 & 0.01 & 0.00 \\
\hline \multicolumn{10}{|l|}{ 2005-2017 } \\
\hline Forest & 2.09 & 0.39 & 0.00 & -0.02 & 0.03 & -0.05 & 0.22 & -0.04 & -1.84 \\
\hline Grassland & 0.03 & 0.07 & 0.02 & 0.00 & 0.01 & 0.00 & 0.01 & 0.00 & 0.01 \\
\hline Water & 0.27 & 0.19 & -0.03 & -0.01 & 0.00 & -0.07 & 0.06 & 0.00 & -0.03 \\
\hline Fishponds & 0.18 & 0.47 & 0.05 & 0.00 & 0.07 & 0.00 & 0.18 & 0.00 & -0.01 \\
\hline Built-up & 1.81 & 0.00 & -0.22 & -0.01 & -0.06 & -0.18 & 0.00 & -0.07 & -1.27 \\
\hline Bareland & 0.05 & 0.18 & 0.04 & 0.00 & 0.00 & 0.00 & 0.07 & 0.00 & 0.02 \\
\hline Farmland & 0.12 & 3.25 & 1.84 & -0.01 & 0.03 & 0.01 & 1.27 & -0.02 & 0.00 \\
\hline
\end{tabular}

\subsection{Simulation}

Transition Potential Modelling and Determining Driving Variables

The land use land cover change results indicated that the significant changes in urban areas occur mainly from the deterioration of farmland and fishponds. The transitions considered in the Land Change Modeler are: forest-built-up, grassland-built-up, water-built-up, fishponds-built-up, bareland-built-up, farmland-built-up, and farmland-forest. All these transitions, based on visual evidence of the urban spatial trend, had the same driving force. Table 4 illustrates the potential explanatory power of each driving force, represented by Cramer's V. The variable that has a Cramer's 
$\mathrm{V}$ value of about 0.15 or higher are useful, while those with values of 0.4 or higher are good. Thus, the selected factors were found to be relevant (Figure 3). Slope show significant influence on urban growth especially in the Pearl River Delta and on the eastern side of the study area. This could be attributed to their relatively flat terrain where the constraints of slope are not as significant as that in the mountainous regions. Both hillshade and aspect indicate exposure to sunlight, which can play a significant role in the selection of land for farmland and urban area encroachment. On the other hand, it is also important factor for the increasing growth of tropical/subtropical forest types in the study area. Hillshade may be correlated with slope and aspect as it reflects the topographic patterns associated with both of them. Other variables are also found to represent an important spatial determination of urban growth. After the selection of the predictor variables, transitions were modelled in one transition sub-model, and generated the transition potential maps through multilayer perceptron with an accuracy of above $70 \%$ (Figure 4 ).

Table 4. Cramer's V values of explanatory variables.

\begin{tabular}{lc}
\hline \multicolumn{1}{c}{ Explanatory Variables } & Cramer's V \\
\hline Slope & 0.3448 \\
Aspect & 0.3107 \\
DEM & 0.2665 \\
Hillshade & 0.2526 \\
Distance to roads & 0.2162 \\
Distance to water channel & 0.1787 \\
\hline
\end{tabular}
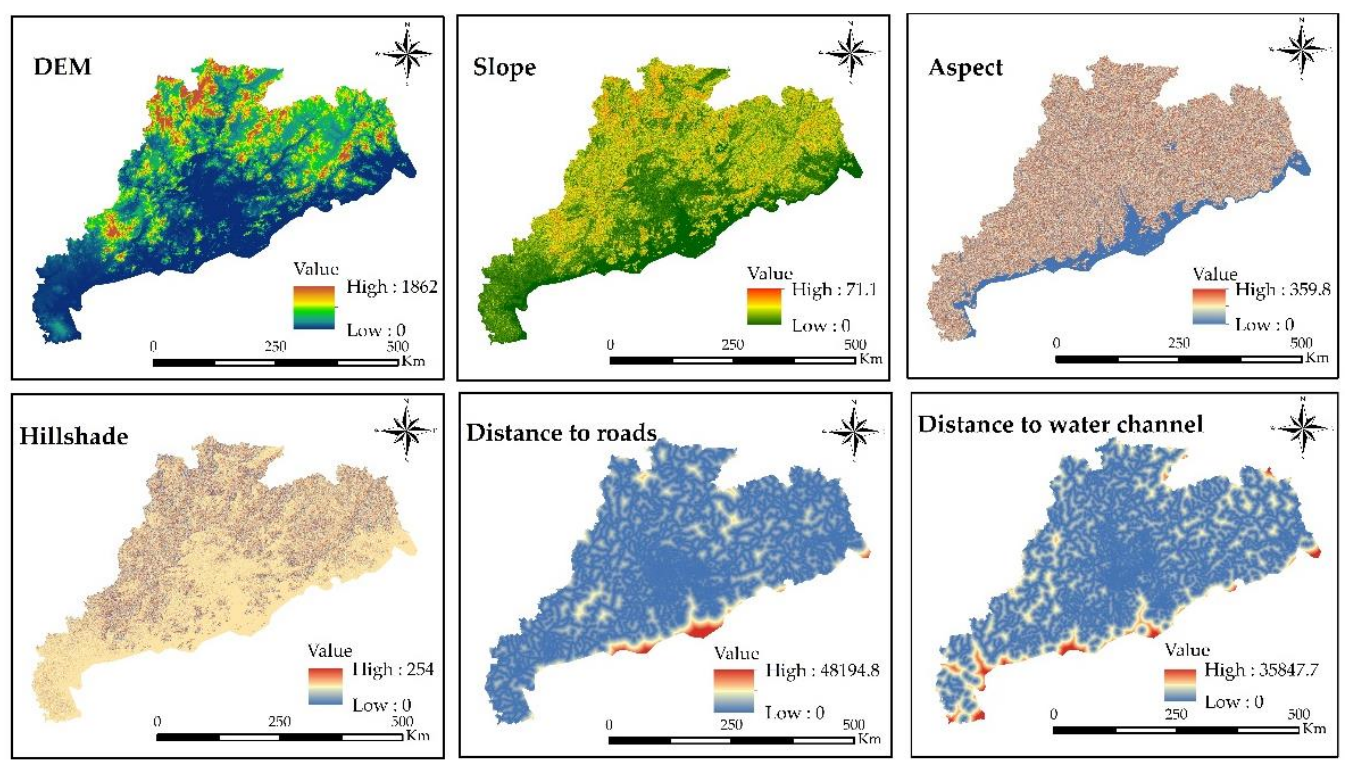

Figure 3. Maps of the variables used for the spatial distribution of land change modeling DEM, slope, aspect, hillshade, distance to roads, and distance to water channel. 

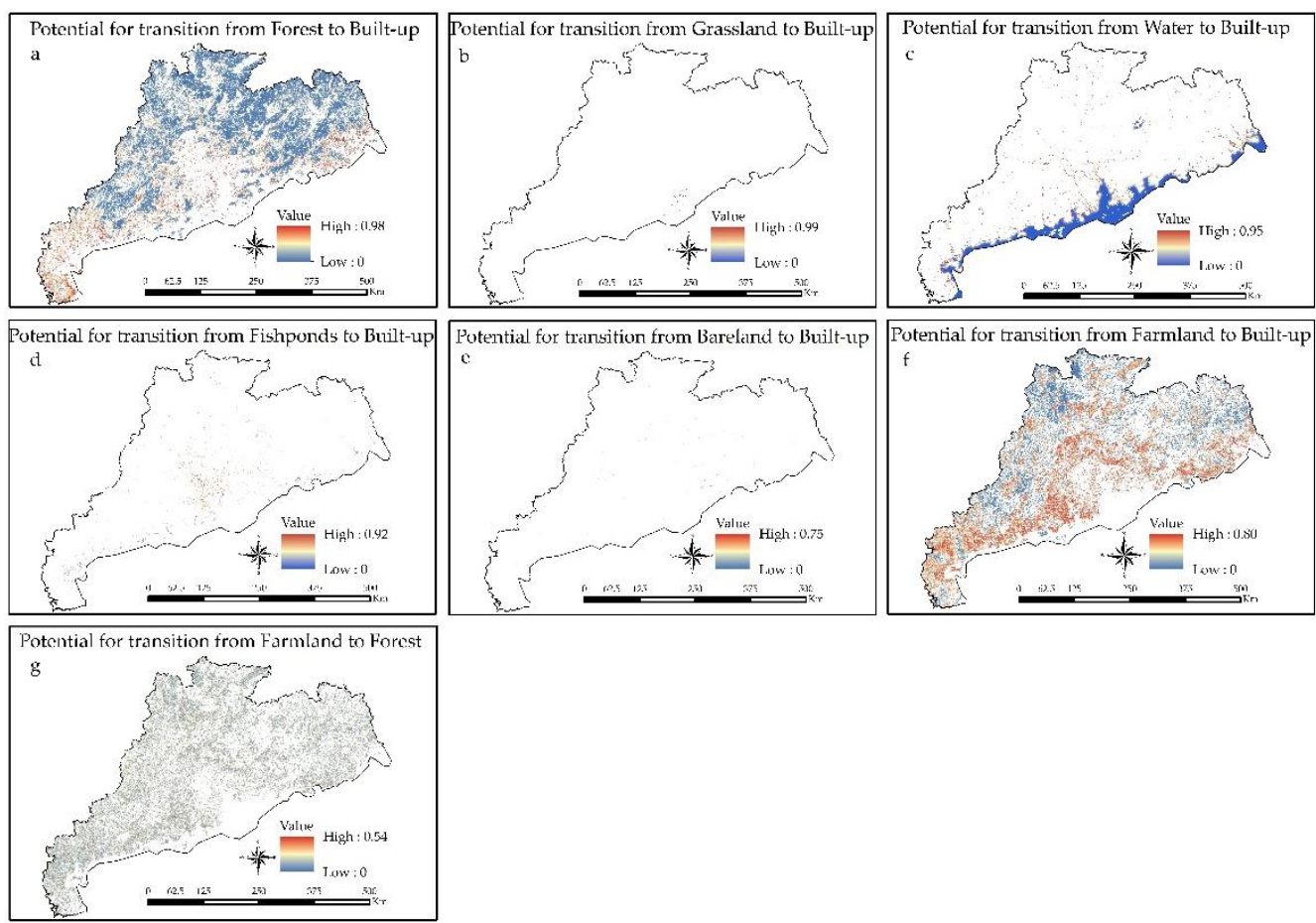

Figure 4. Transition potential maps from (a) forest to built-up (b) grassland to built-up, (c) water to built-up, (d) fishponds to built-up, (e) bareland to built-up, (f) farmland to built-up, and (g) farmland to forest.

\subsection{Land Use Land Cover Transition Analysis}

In this study, the transition probability matrices were produced for the years 2017 (using 2005 and 2010 land use land cover layers), 2024 (using 2010 and 2017 land use land cover layers), and 2031 (using 2010 and 2017 land use land cover layers) (Tables 5-7). The transition probability matrix shows the probability of a conversion for each land use land cover class to another class, within the specified time. The change of probabilities between two different time periods reveal the significant increase of urban areas at the cost of a decrease in farmland and fishponds in the Guangdong, Hong Kong, and Macao region.

Table 5. Transition probability matrix of land use land cover classes for the year 2017.

\begin{tabular}{cccccccc}
\hline Classes & Forest & Grassland & Water & Fishponds & Built-Up & Bareland & Farmland \\
\hline Forest & 0.9789 & 0.0007 & 0.0033 & 0.0054 & 0.0104 & 0.001 & 0.0000 \\
Grassland & 0.3594 & 0.0926 & 0.054 & 0.0708 & 0.0712 & 0.0026 & 0.3495 \\
Water & 0.0141 & 0.0001 & 0.9385 & 0.0306 & 0.0087 & 0.0004 & 0.0076 \\
Fishponds & 0.1502 & 0.0006 & 0.2139 & 0.2888 & 0.2244 & 0.0017 & 0.1204 \\
Built-up & 0.0000 & 0.0000 & 0.0000 & 0.0000 & 1.0000 & 0.0000 & 0.0000 \\
Bareland & 0.0851 & 0.0016 & 0.0242 & 0.024 & 0.3149 & 0.0098 & 0.5404 \\
Farmland & 0.0606 & 0.0000 & 0.0025 & 0.0035 & 0.0555 & 0.0008 & 0.877 \\
\hline
\end{tabular}


Table 6. Transition probability matrix of land use land cover classes for the year 2024 .

\begin{tabular}{cccccccc}
\hline Classes & Forest & Grassland & Water & Fishponds & Built-Up & Bareland & Farmland \\
\hline Forest & 0.9615 & 0.0007 & 0.0076 & 0.0069 & 0.0223 & 0.001 & 0.0000 \\
Grassland & 0.4148 & 0.0152 & 0.0715 & 0.0347 & 0.1167 & 0.0012 & 0.3459 \\
Water & 0.0324 & 0.0001 & 0.8876 & 0.037 & 0.0246 & 0.0005 & 0.0178 \\
Fishponds & 0.1982 & 0.0004 & 0.2587 & 0.106 & 0.2956 & 0.0009 & 0.1403 \\
Built-up & 0.0000 & 0.0000 & 0.0000 & 0.0000 & 1.0000 & 0.0000 & 0.0000 \\
Bareland & 0.1211 & 0.0004 & 0.0294 & 0.0114 & 0.3541 & 0.001 & 0.4827 \\
Farmland & 0.113 & 0.0001 & 0.0055 & 0.0045 & 0.1057 & 0.0008 & 0.7705 \\
\hline
\end{tabular}

Table 7. Transition probability matrix of land use land cover classes for the year 2031.

\begin{tabular}{cccccccc}
\hline Classes & Forest & Grassland & Water & Fishponds & Built-Up & Bareland & Farmland \\
\hline Forest & 0.9445 & 0.0007 & 0.0119 & 0.0075 & 0.0344 & 0.0010 & 0.0000 \\
Grassland & 0.4389 & 0.0017 & 0.0776 & 0.0166 & 0.1502 & 0.0008 & 0.3142 \\
Water & 0.0509 & 0.0001 & 0.8411 & 0.0381 & 0.0421 & 0.0005 & 0.0272 \\
Fishponds & 0.2224 & 0.0002 & 0.2667 & 0.0396 & 0.3319 & 0.0006 & 0.1385 \\
Built-up & 0.0000 & 0.0000 & 0.0000 & 0.0000 & 1.0000 & 0.0000 & 0.0000 \\
Bareland & 0.1502 & 0.0001 & 0.0317 & 0.0066 & 0.3853 & 0.0006 & 0.4256 \\
Farmland & 0.1582 & 0.0001 & 0.0084 & 0.0048 & 0.151 & 0.0008 & 0.6767 \\
\hline
\end{tabular}

Table 5 shows that forest and built-up are the most stable classes with respective probabilities of 0.97 and 1.00. Water, farmland, and fishponds are the most dynamic classes with transition probabilities of $0.93,0.87$, and 0.28 . In these land use land cover classes, farmland was mainly converted into built-up land and forest cover, whereas, fishponds were primarily transformed into built-up land. The occupation of both farmland and fishponds by an urban sprawl is evident. From Tables 6 and 7 the transition of several land use land cover classes shows a consistency with the previous periods. Forest and built-up land are still the most stable classes with respective transition probabilities 0.96 and 1.00 (Table 6), and 0.94 and 1.00 (Table 7). The most dynamic classes are farmland and fishponds, which primarily transformed into built-up land with respective transition probabilities 0.1057 and 0.2956 (Table 6), and 0.151 and 0.3319 (Table 7). The transformation of farmland into forest had a probability of 0.113 Table 6 and 0.1582 Table 7 indicates that different afforestation policies will continue to play a significant role in making greener Guangdong, Hong Kong, and Macao.

\subsection{Validation}

Simulated and actual land use land cover maps of 2017 are shown in Figure 5. Their area statistics of different land use land cover classes are shown in Table 8. Visual interpretation of the modeling results shows that the simulated map for the year 2017 is reasonably similar to the actual map for that year. A more detailed analysis was accomplished using the Kappa variations and relative operating characteristics. Kappa variations that compared the projected land use land cover map with the actual land use land cover map of the year 2017 resulted in a Kappa value $=0.97, \mathrm{~K}_{\text {no }}=0.97$, Kappa location $=0.99$, and $\mathrm{k}$ standard $=0.96$, whereas the relative operating characteristics value, i.e., area under the curve is 0.914 (Figure 6). Thus, high values of both Kappa and relative operating characteristics suggest that the majority of the study area experienced no change, indicating the consistency is quite strong between the predicted results and the actual land use situation. However, model predict less forest cover and more built-up area and fishponds than the actual land cover map. Both Kappa and relative operating characteristics results confirms that the model is reliable for the Guangdong, Hong Kong, and Macao and can be used to predict future land use land cover change under different scenarios. 

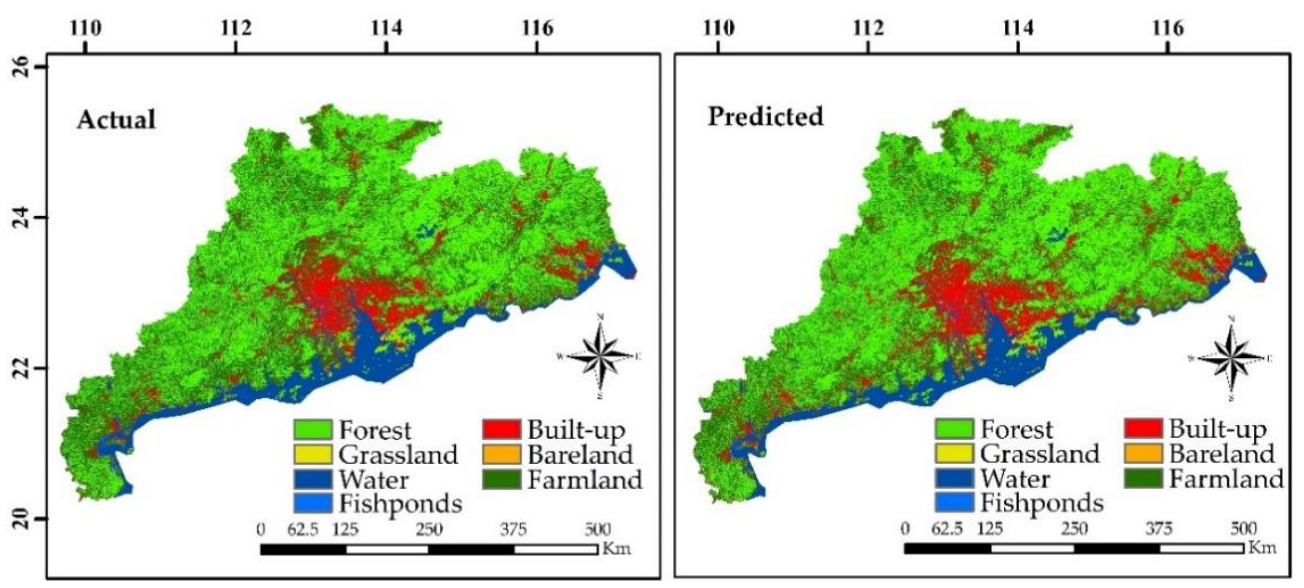

Figure 5. Actual and simulated land use land cover map for the year 2017 of the Guangdong, Hong Kong, and Macao.

Table 8. Area statistics of actual and predicted land use land cover map of 2017.

\begin{tabular}{ccc}
\hline Classes & Actual & Predicted \\
\cline { 2 - 3 } & $\mathbf{k m}^{\mathbf{2}}$ & $\mathbf{k m}^{\mathbf{2}}$ \\
\hline Forest & $88,391.98$ & $86,835.34$ \\
Grassland & 189.47 & 133.06 \\
Water & $20,656.34$ & $20,035.57$ \\
Fishponds & 1663.83 & 1902.80 \\
Built-up & $20,228.95$ & $21,975.24$ \\
Bareland & 275.21 & 149.66 \\
Farmland & $64,938.68$ & $65,311.12$ \\
\hline
\end{tabular}

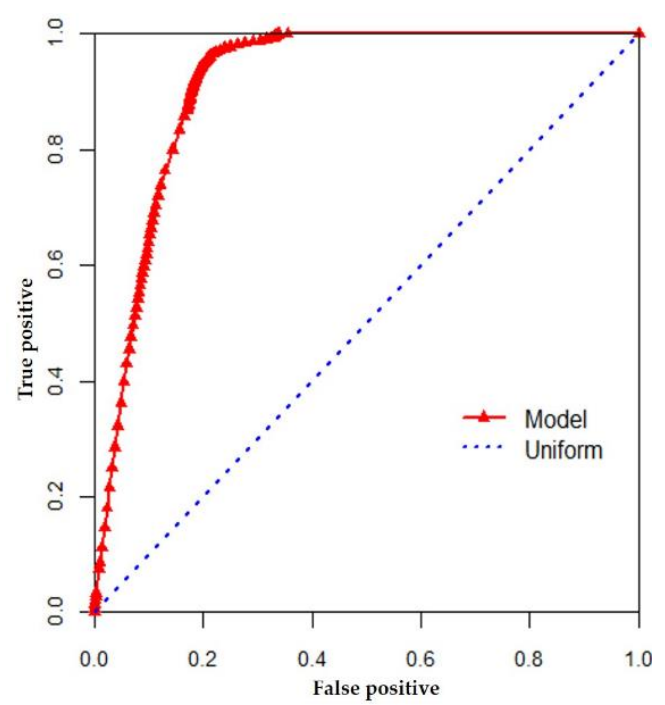

Figure 6. Relative operative characteristics (ROC) curve which provide the correlation between the predicted and actual land use land cover map. The closer the curve approaches the upper left corner, the stronger is the predictive power of the model. For this study relative operative characteristic value is 0.914 , indicating strong consistency between the predicted and actual land use land cover map.

\subsection{Future Scenario/Simulation}

After successful validation of the model, based on real land use land cover maps the model predicted the urban growth and the land use land cover maps for the years 2024 and 2031 (Figure 7). The markov model also provides the transition probability matrix for the years 2024 and 2031 (Tables 6 
and 7). The statistical change analysis of projected land cover is shown in Table 9. The model predicts that built-up land will continue to increase by $15,710.20 \mathrm{~km}^{2}(136.90 \%)$ in 2024 and $20,518.78 \mathrm{~km}^{2}$ $(178.80 \%)$ in 2031 , compared to $11,475.77 \mathrm{~km}^{2}$ in 2005 , to the detriment of a decrease of farmland and fishponds (Table 9). Farmland will decrease by $22,313.79 \mathrm{~km}^{2}$ in 2024 and $29,000.81 \mathrm{~km}^{2}$ in 2031, compared to the $80,043.82 \mathrm{~km}^{2}$ in 2005 . Fishponds will decrease by $1331.81 \mathrm{~km}^{2}$ and $1420.87 \mathrm{~km}^{2}$ in 2024 and 2031, compared to $3059.93 \mathrm{~km}^{2}$ in 2005 . However, forest cover will continue to increase by $9536.49 \mathrm{~km}^{2}$ and $11,869.30 \mathrm{~km}^{2}$ in 2024 and 2031, compared to $80,180.31 \mathrm{~km}^{2}$ in 2005 (Table 9). The overall change in the land use land cover in the predicted years is shown in Figure 8. In summary, the predicted results confirm that such patterns will continue in future because of the results of China's economic hub, economic policy, housing, industry, and development of the infrastructure. These changes have adverse impacts on the urban environment. Therefore, with the help of future prediction results, proper planning and environmental management plans can control the adverse effect of these changes.
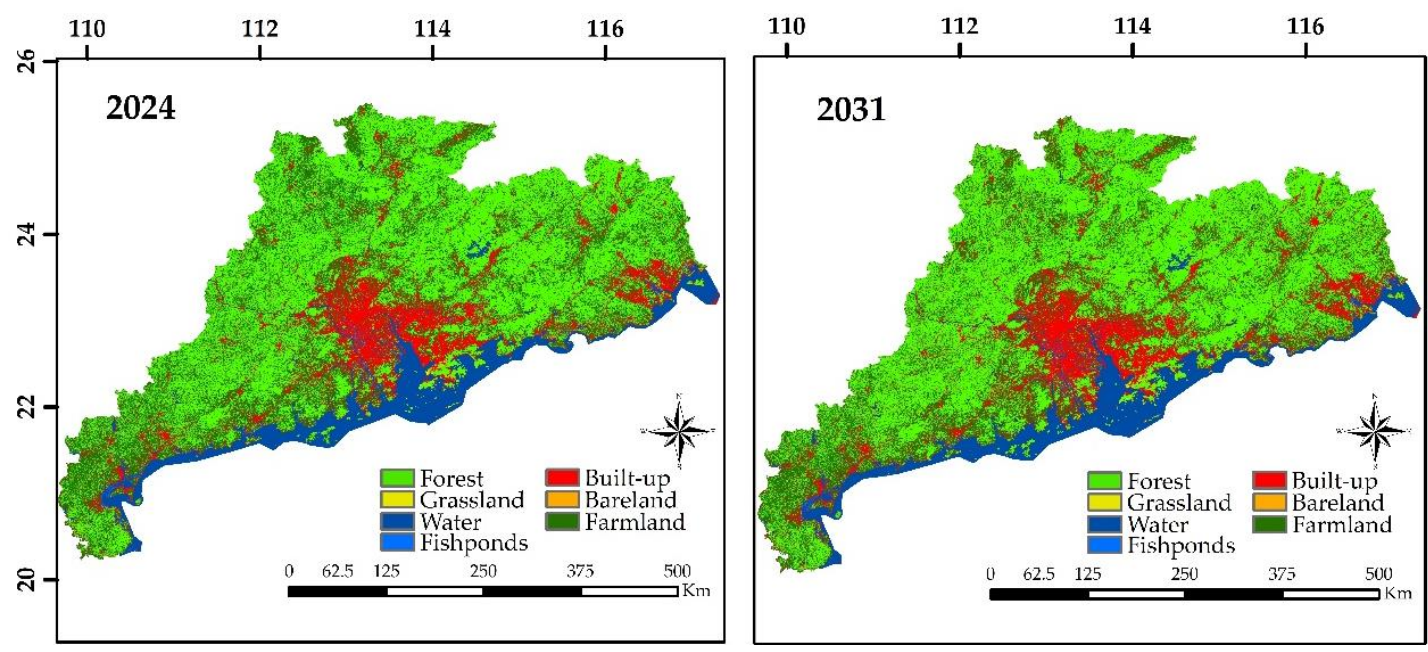

Figure 7. Predicted land use land cover map for the years 2024 and 2031.

Table 9. Area statistics of the projected land use land cover classes in 2024 and 2031.

\begin{tabular}{cccccccccc}
\hline & $\mathbf{2 0 1 7}$ & $\mathbf{2 0 2 4}$ & $\mathbf{2 0 3 1}$ & \multicolumn{2}{c}{$\begin{array}{c}\text { Change } \\
\mathbf{2 0 1 7 - 2 0 2 4}\end{array}$} & $\begin{array}{c}\text { Change } \\
\mathbf{2 0 1 7 - 2 0 3 1}\end{array}$ & Change & $\begin{array}{c}\text { Change } \\
\mathbf{2 0 0 5 - 2 0 3 1}\end{array}$ & Change \\
\hline Classes & $\mathbf{k m}^{\mathbf{2}}$ & $\mathbf{k m}^{\mathbf{2}}$ & $\mathbf{k m}^{\mathbf{2}}$ & $\mathbf{k m}^{\mathbf{2}}$ & $\mathbf{\%}$ & $\mathbf{k m}^{\mathbf{2}}$ & $\mathbf{\%}$ & $\mathbf{k m}^{\mathbf{2}}$ & $\mathbf{\%}$ \\
\hline Forest & $88,391.98$ & $89,716.81$ & $92,049.62$ & 1324.83 & 1.50 & 3657.64 & 4.14 & $11,869.30$ & 14.80 \\
Grassland & 189.47 & 126.54 & 121.74 & -62.93 & -33.21 & -67.72 & -35.74 & -278.10 & -69.55 \\
Water & $20,656.34$ & $19,714.21$ & $19,360.51$ & -942.13 & -4.56 & -1295.82 & -6.27 & -889.35 & -4.39 \\
Fishponds & 1663.83 & 1728.12 & 1639.06 & 64.29 & 3.86 & -24.77 & -1.49 & -1420.87 & -46.43 \\
Built-up & $20,228.95$ & $27,185.97$ & $31,994.55$ & 6957.03 & 34.39 & $11,765.61$ & 58.16 & $20,518.78$ & 178.80 \\
Bareland & 275.21 & 141.09 & 134.27 & -134.12 & -48.73 & -140.94 & -51.21 & -800.20 & -85.63 \\
Farmland & $64,938.68$ & $57,730.03$ & $51,043.01$ & -7208.65 & -11.10 & $-13,895.67$ & -21.40 & $-29,000.81$ & -36.23 \\
\hline
\end{tabular}



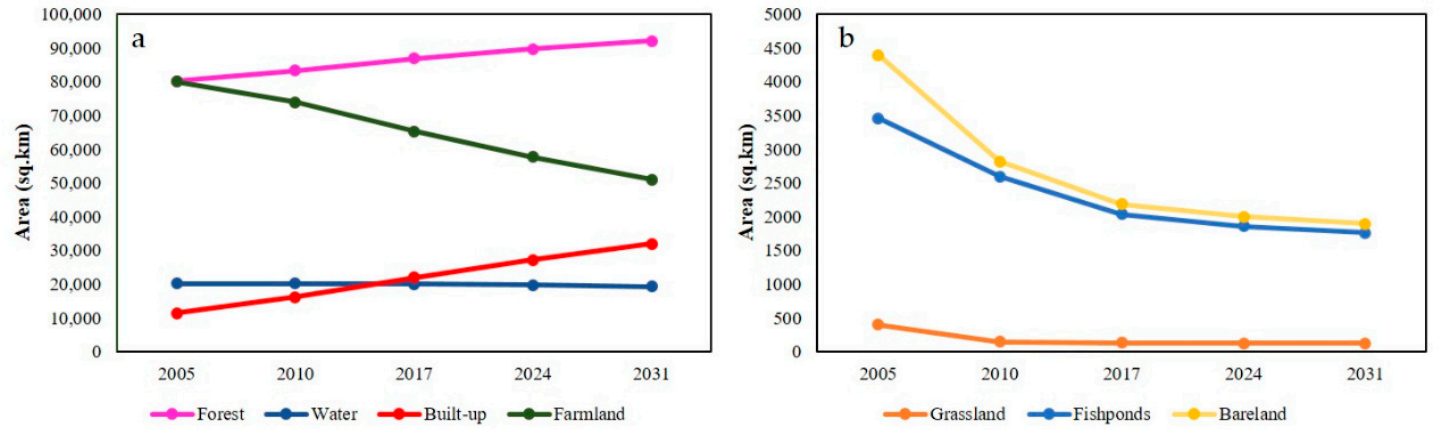

Figure 8. Area of the land use land cover classes (a) forest, water, built-up, and farmland, (b) grassland, fishponds, and bareland over the years 2005, 2010, 2017, and predicted 2024 and 2031.

Furthermore, it can be concluded from gain and loss Table 10 that farmland will be adversely influenced by an upsurge in other land use types, specifically built-up areas. A significant gain in both built-up and forest has been recorded because of the socioeconomic development process and different land use policies such as the land administration law (LAL). Table 10 also shows the contribution to net change in each land use land cover category, both positively and negatively in the Guangdong, Hong Kong, and Macao during 2005-2031. It is worth noting that the loss of farmland was mostly transferred into two classes, i.e., (1) forest $\left(18,093.67 \mathrm{~km}^{2}\right)$ and (2) built-up $\left(11,323.29 \mathrm{~km}^{2}\right)$. Table 10 shows that the loss of fishponds dominantly converted into built-up area $\left(1320.78 \mathrm{~km}^{2}\right)$. Due to continuous increase in urban growth and development, the green ecosystem in the Guangdong, Hong Kong, and Macao will be significantly influenced, making it crucial for local institutions to establish exacting policies to protect and preserve the local environment in the long haul.

Table 10. Gains, losses, and contributions to net change in each land use land cover types in the Guangdong, Hong Kong, and Macao during 2005-2031.

\begin{tabular}{cccccccccc}
\hline 2005-2031 & Gain & Loss & \multicolumn{7}{c}{ Net Contribution } \\
\hline Classes & & & Forest & Grassland & Water & Fishponds & Built-Up & Bareland & Farmland \\
\hline & $\%$ & $\%$ & $\%$ & $\%$ & $\%$ & $\%$ & $\%$ & $\%$ & $\%$ \\
Forest & 3.95 & 0.52 & 0.00 & -0.02 & 0.03 & -0.03 & 0.37 & -0.04 & -3.75 \\
Grassland & 0.02 & 0.07 & 0.02 & 0.00 & 0.01 & 0.00 & 0.02 & 0.00 & 0.00 \\
Water & 0.24 & 0.24 & -0.03 & -0.01 & 0.00 & -0.08 & 0.15 & -0.01 & -0.03 \\
Fishponds & 0.15 & 0.49 & 0.03 & 0.00 & 0.08 & 0.00 & 0.27 & 0.00 & -0.03 \\
Built-up & 3.27 & 0.00 & -0.37 & -0.02 & -0.15 & -0.27 & 0.00 & -0.11 & -2.35 \\
Bareland & 0.03 & 0.19 & 0.04 & 0.00 & 0.01 & 0.00 & 0.11 & 0.00 & 0.01 \\
Farmland & 0.05 & 6.20 & 3.75 & 0.00 & 0.03 & 0.03 & 2.35 & -0.01 & 0.00 \\
\hline
\end{tabular}

In order, to examine and understand the influence of land use land cover change on green lands (i.e., forest and farmland) and the key role of urbanization, Figure 9 shows the conversion of farmland and forest into other land use types. The spatial visualization provided by the Land Change Modeler shows that, in the next 14 years, built-up areas represent the most momentous land use land cover class and will negatively affect the farmlands. Figure $9 \mathrm{~b}$ shows that the forest cover will continue to increase in the Guangdong, Hong Kong, and Macao over the next 14 years. 

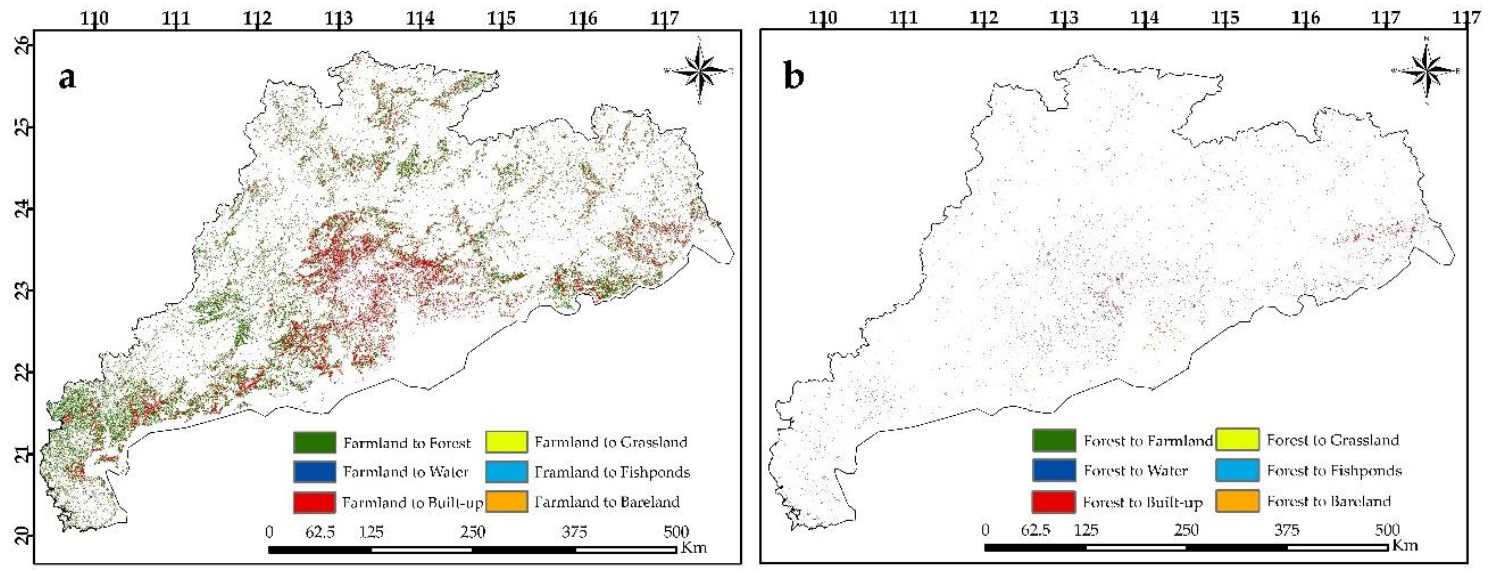

Figure 9. Transition from (a) farmland to all categories and (b) forest to all categories between 2005 and 2031.

\subsection{Landscape Metrics and Urban Analysis}

Figure 10 reflects the changes in spatial morphology of the landscape at class and landscape level. With the increase in the 'percentage of the landscape' of both forest cover and built-up land, the patch density and edge density increased significantly (Figure 10a-c). The patch density for forests cover increased from 0.46 to 0.53 , and for built-up areas from 0.35 to 0.49 during 2005-2017, and will continue to increase during 2017-2031 (Figure 10b). This signifies the considerable growth of landscape complexity with the increasing human-induced activities. The largest patch index increases for both forest cover (from $4.06 \%$ to $7.33 \%$ ) and built-up land (from $0.35 \%$ to $1.03 \%$ ) during $2005-2017$ and predicted result show that it will continue to increase to $11.60 \%$ in 2024 and $12.21 \%$ in 2031 (Figure 10d). This indicates the corresponding patch type uniformity. A 'mean patch area', which is a critical measure of habitat fragmentation, will decrease for forest cover from 36.17 ha in 2005 to 30.72 ha in 2031, and increase for built-up land from 6.71 ha in 2005 to 11.10 ha in 2031. Smaller 'mean patch area' together with larger 'patch density' and 'largest patch index' for forest cover revealed fragmentation. However, a larger 'mean patch area' together with larger 'patch density' and 'largest patch index' for built-up land reflects that the landscape is expected to gradually became urban dominated as the intensity of urbanization in the fringe as well as densification within already urbanized area increased tremendously, leading to the dominance of urban landscape. The mean Euclidian nearest neighbor distance (ENN_MN) shows an expected decrease for both forest and built-up land during 2005-2031 (Figure 10g). This indicates that the spaces between their neighbors decreases with time due to high industrialization and unprecedented population density, thus suggesting coalescence.

The 'percentage of landscape' of both farmland and fishponds decreased substantially during the study period. For farmland, the decrease in the 'mean patch area', 'largest patch index' and increase in 'patch density' reflect that farmland is highly fragmented (Figure 10b,d,f). The 'mean patch area' decreased from 38.94 ha in 2005 to 24.04 ha in 2017 and will continue to decrease to 16.64 ha in 2024 and 12.03 ha in 2031. The 'largest patch index' showed the similar trend as a result of gradual urban encroachment. In contrast 'edge density', increases from $16.77 \mathrm{~m} / \mathrm{ha}$ to $21.17 \mathrm{~m} / \mathrm{ha}$ during 2005-2031 indicating that the landscape patches turn to be complex. However, the value of 'mean Euclidian nearest neighbor distance' decreases from $220.56 \mathrm{~m}$ in 2005 to $211.41 \mathrm{~m}$ in 2031, indicating coalescence. For fishponds, the 'patch density' decreases substantially, i.e., from 0.17 in 2005 to 0.09 in 2031, indicating aggregated fishponds areas. Similarly, a significant reduction occurred in the 'mean patch area', 'largest patch index', and 'edge density' during 2005-2017 and they will continue to decrease during 2017-2031 (Figure 10c,e,f). 

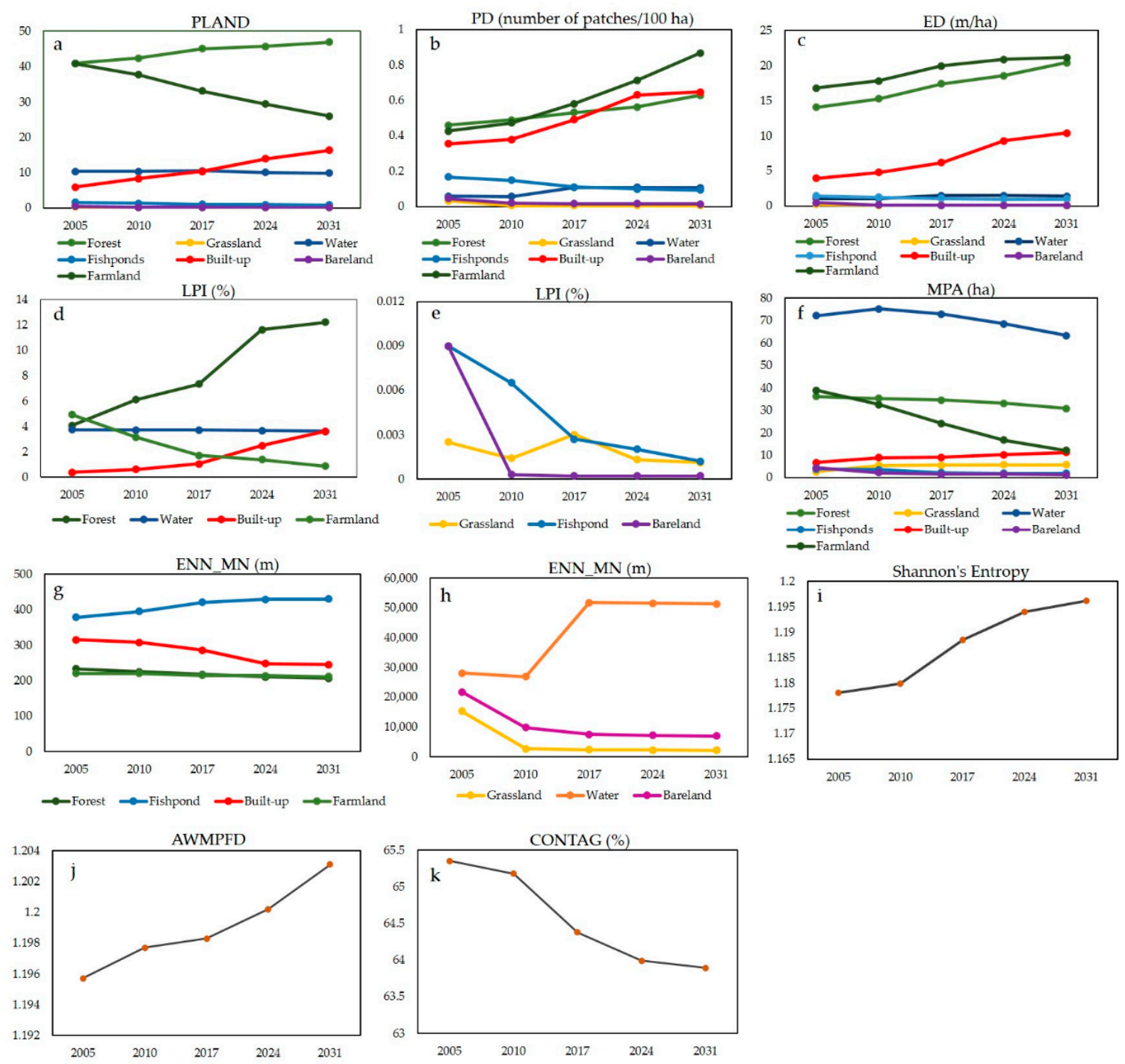

Figure 10. Temporal patterns of landscape metrics from 2005 to 2031 (a) Percentage of landscape (PLAND), (b) Patch density (PD), (c) Edge density (ED), (d,e) Largest Patch Index (LPI), (f) Mean patch area (MPA), and (g,h) Euclidian Mean Nearest Neighbor Distance (ENN_MN) at class level, whereas, (i) Shannon's diversity index (SDI), (j) Area Weighted Mean Fractal Dimension (AWMPFD), and (k) Contagion (CONTAG)) at landscape level.

Due to more dispersed distribution, fragmentation, and heterogeneity in the landscape, 'Shannon's diversity index' and 'area weighted mean fractal dimension' increases while contagion value decreases during 2005-2017 and predicted resulted shows that such trend will continue during 2017-2031 (Figure 10i-k). This indicates that urban growth will continue in the form of an increasing number of clusters as well as the expansion of existing urban centers. On the hands, forest patches will increase and merged to form contiguous patches thus increasing proportion in the landscape and dominating land cover type. Decrease in farmland can be exacerbated due to isolation as indicated by increasing trend in patch density and reduction in the relative proportion in the landscape. This demonstrates that land development will continue to spread over the urban peripheral areas and into the neighboring rural areas. It will be important for policy makers to carefully design and monitor urban growth with the least impact on the farmland fragmentation. 


\section{Discussion}

After the settlement of political insurgency in 1978, the pace of infrastructure development, socioeconomic development, industrialization, and urbanization accelerated in the Guangdong, Hong Kong, and Macao. There is a complex relationship between land use land cover change, anthropogenic activities, and sustainable future environment [2]. Today, a large number of land use land cover and urban growth models have been developed which provide ability to choose a model according to the characteristics of the area of interest and the research questions $[17,18,73]$. In this study, Land Change Modeler was used to predict the land use land cover changes for the next fourteen years. Long-term simulations can be used as a guide for urban studies by giving future forecasts of possible changes under existing patterns and circumstances [30,81]. However, with the increase in simulation periods, the simulated results may be adversely affected. For example, land use land cover and transportation system are the two utmost imperative sub-systems that influences the long-term shape of a city. With time, they commonly influence each other [82], and may also affect the demands for travel and access. Construction or expansion of new or existing roads, for example, directly influences the settlements location and density. Thus, it is assumed, that the network of static transportation creates a substantial drawback for simulations of long-term urban development. In this regard, models have shortcoming in temporal dynamics $[30,81,83]$. Thus, for this study, on the basis of the continuity of the past trends of 2005-2017, projected maps for the years 2024 and 2031 have been simulated. To validate the model, the simulated image was compared with the actual land use land cover image of the same year, i.e., for 2017, all the Kappa values and relative operating characteristics value were greater than $80 \%$. The accuracy of this study shows consistency with previous studies, in which Land Change Modeler and Landsat images were used [8,9,12,16,18,20,30,55,61,84,85].

\subsection{Future Consequences of Land Use Land Cover Changes: Built-Up and Farmland}

After the opening of the economic corridor, the Chinese government launched a series of policies such as the "Household Production Responsibility System (HPRS)" and the "market-directed economic system". These policies have headed explicit conversion of land use land cover, such as transformation of farmland into built-up land [86]. During 2005-2017, the built-up area boomed from 5.84\% to $10.31 \%$ and the modeling results confirm that it will continue to increase to $16.30 \%$ by 2031 , at the cost of a substantial reduction in both farmland (from $40.77 \%$ in 2005 to $26.00 \%$ in 2031) and fishponds (from $1.56 \%$ to $0.83 \%$ during $2005-2031$ ). This trend is also reflected in the landscape metrics, i.e., patch density, largest patch index, and edge density increasing for built-up land and decreasing for fishponds, whereas mean patch area decreases for both of them. Therefore, in each successive period, a high industrialization rate and socioeconomic development causes the expansion of built-up land beyond the administrative boundary of the counties, and urban growth exceeded the outskirts of the surrounding regions. This is also because of increase in household income/personal income level, living standards, and a reduction in traditional farming activities [8]. However, the continuous development of historical city centers, more fragmented growth, and increasing coalescence between land cover neighbor's causes a decrease in the mean Euclidian nearest neighbor distance of built-up land and farmland. Moreover, an increase in Shannon's diversity index claims a high urban rate and dispersion of urban development within the period of study, causing a noteworthy influence on the urban periphery [6]. With the increase in fragmentation, the contagion value decreased due to more individual units such as urban units.

These changes are more pronounced in the Pearl River Delta (PRD) and on the east flank of the Guangdong, Hong Kong, and Macao. These two regions account for 57\% of the Guangdong, Hong Kong, and Macao's total population [44]. The probable reason is that these regions lie at a low elevation, and are more suitable for settlement than the high-elevated areas. Thus, the unprecedented growth of built-up areas has overwhelmed the primitive rural areas and encompass an economic corridor from the PRD and the eastern sides towards the surrounding outskirts $[8,18]$. However, an 
increase in the proportion of urban dwellers have confirmed a rising competition between consumers in the property and land market [3].

Such changes in land cover are attributed to the land use land cover regulations, which allowed the sale of the state ownership land in the property market, while the sale of collective land ownership is not allowed [11]. This rapid development of built-up land has significantly contributed to provide much lose space for other land use types, such as built-up areas. Additionally, the reason for the conversion of farmland into urban land is that the local government confiscated collectively owned farmland for public and commercial purposes and remunerated farmers for the loss of the affected lands. The confiscated land then became state-owned and the rights of its land use transferred by sale, tender, or agreement. A special market substance was established by the government and its related operational departments [11].

Thus, these simulated results helped urban planners and policy decision makers to learn that further expansion of urban land and urban population could result in increased traffic jams, transformation of open spaces, increased travel time, residential energy consumption [87], and changes in living standards [11].

\subsection{Proximate and Underlying Factors}

Proximate and underlying factors of communal facility availabilities and rural urban connections [2] have also ominously played a key role in the population migration in the Guangdong, Hong Kong, and Macao. The distance from roads and distance from water channels are also considered an imperative spatial determinant for urban development, thus indicating that non-urban areas near to the city center have a higher probability of being converted into built-up land. Such areas were ripe for further urban planning [8]. The next important factors for urban growth were slope, aspect, and hillshade [2,8]. The unparalleled combination of economic development, population, and the unintended byproducts of the growth of government policies has contributed to the social structure change of the Guangdong, Hong Kong, and Macao from a largely rural society to an urban society. Most importantly, urbanization and industrialization have significantly provoked farmland reduction in the Guangdong, Hong Kong, and Macao [11,86]. All the above mentioned drivers should be considered by policy decision makers when addressing land use development and the resulting key sustainability problems [2].

\subsection{Forest Cover Increases}

During 2005-2017, forest cover increased to $45.02 \%$ from $40.84 \%$ and simulation results show that it will continue to increase to $46.88 \%$ in 2031. This trend can also be observed in the increasing patch density, largest patch index, and edge density of forest cover. Of further interest, mean Euclidian nearest neighbor distance of forest cover decreased as the distance between forest neighbors shrank. This increase in forest cover indicates that forest policies and afforestation programs is likely to continue in the study area. These programs may include "China Biodiversity Conservation Action Plan (1994) (CBCAP)" [88], the "Forestry Action Plan for China's Agenda 21 (1995) (FAPCA)" [89], the "China Ecological Environment Conservation Plan (1998) (CEECP)", the "China Wetland Protection Action Plan (2000) (CWPAP)", the "China Mangrove Protection Management (CMPM)", and the "Utilization Plan (2002) (UP)" [86,89]. Forest cover in China, also increased because of the development of eucalyptus plantations on a large scale. The plantation of eucalyptus is not only limited to Guangdong, but also in most of southern China, e.g., Guangxi, Sichuan, Yunnan, Hainan, and Fujian provinces, because of the high demand for timber products and high ecological value. The development of eucalyptus plantations on a large scale for logging, however, also prompted the conversion of farmland. Therefore, to protect farmland conversion, it is essential to control the demand of timber products using numerous methods, such as decreasing the usage of disposable chopsticks and avoid the wastage of paper [87]. The significant growth of eucalyptus has caused a set of potential ecological issues, such as water deprivation, biodiversity loss, and fertilizer consumption [86]. 
In summary, the future simulation of land use land cover change, based on the land change modeler, has significant ramifications for the urban planning and management of the Guangdong, Hong Kong, and Macao [11]. The simulated results, given above in Sections 3.5 and 3.6, provide significant insights into the future land use land cover development and will hence provide a better understanding of the area's growth patterns and the necessity for suitable sustainable development, together with the protection of farmland during planning development. To a large extent, when planning a city or city growth, the consequences of urban sprawl represent a necessary consideration.

\section{Conclusions}

During the last two decades, the Guangdong, Hong Kong, and Macao (GHKM) has experienced substantial changes in land use land cover with induced socioeconomic activities. This study has examined the features of land use land cover change and simulated future land use land cover and urban growth of the GHKM using Land Change Modeler (LCM). To validate the model, the projected 2017 land use land cover map was compared with 2017 actual land use land cover map. After successful model validation, the land use land cover map for the years 2024 and 2031 are predicted. The simulated results showed an expected increase in built-up areas from $10.31 \%$ in 2017 to $16.30 \%$ in 2031 with the substantial decrease in farmland from $33.03 \%$ to $26.00 \%$ and fishponds from $0.97 \%$ to $0.83 \%$ during $2017-2031$. Forest cover, however, will increase from $45.02 \%$ in 2017 to $46.88 \%$ in 2031 due to afforestation programs and reduction in farming activities. The spatial structure analysis of the landscape exhibits more disperse, heterogeneous, and fragmented landscape in future. Such changes in land use land cover are attributed to intense socioeconomic development, industrialization, and continuously sprawling urban fabric in urban pockets at suburban and peripheral areas. This unprecedented urbanization and an alarming loss of farmland could ultimately threaten to natural resources and food security. However, timely actions must be taken by urban planners and policy-decision makers to enable sustainable development as well as the protection of farmlands and other natural resources.

Author Contributions: Formal analysis, S.H. and S.A.; Investigation and Methodology, S.H.; Resources and Supervision, W.S.; Writing-original draft, S.H.; Writing-review \& editing, S.H., W.S., X.Z., S.A., and H.U.A.K. All authors have read and agreed to the published version of the manuscript.

Funding: This research was supported by Ministry of Science and Technology of the People's Republic of China, grant number 2019YFB21,03102; The Hong Kong Polytechnic University, grant number 4-9A6X and 1-ZVN6; and Research Grant Council, HKSAR, grant number B-Q61E.

Acknowledgments: The authors would like to thank USGS Earth Explorer for providing Landsat data. The authors would also like to thanks the anonymous reviewers for their insightful comments and substantial help on improving this article.

Conflicts of Interest: The authors declare no conflict of interest.

\section{References}

1. Shafizadeh, H.M.; Helbich, M. Spatiotemporal urbanization processes in the megacity of Mumbai, India: A Markov chains-cellular automata urban growth model. Appl. Geogr. 2013, 40, 140-149. [CrossRef]

2. Rimal, B.; Zhang, L.; Keshtkar, H.; Wang, N.; Lin, Y. Monitoring and Modeling of Spatiotemporal Urban Expansion and Land-Use/Land-Cover Change Using Integrated Markov Chain Cellular Automata Model. Int. J. Geo Inf. 2017, 6, 288. [CrossRef]

3. Chen, J.; Guo, F.; Wang, H.; Wang, Z.; Wu, Y. Urban Land Revenue and Sustainable Urbanization in China: Issues and Challenges. Sustainability 2018, 10, 2111. [CrossRef]

4. Li, F.; Ye, Y.P.; Song, B.W.; Wang, R.S.; Tao, Y. Assessing the changes in land use and ecosystem services in Changzhou municipality, Peoples' Republic of China, 1991-2006. Ecol. Indic. 2014, 42, 95-103. [CrossRef]

5. Zheng, W.; Ke, X.; Zhou, T.; Yang, B. Trade-offs between cropland quality and ecosystem services of marginal compensated cropland-A case study in Wuhan, China. Ecol. Indic. 2018, 105, 613-620. [CrossRef]

6. Araya, Y.H.; Cabral, P. Analysis and Modeling of Urban Land Cover Change in Setúbal and Sesimbra, Portugal. Remote Sens. 2010, 2, 1549-1563. [CrossRef] 
7. Bongaarts, J. United Nations Department of Economic and Social Affairs Population Division. Popul. Dev. Rev. 2017, 40, 380. [CrossRef]

8. Wang, J.; Maduako, I.N. Spatio-temporal urban growth dynamics of Lagos Metropolitan Region of Nigeria based on Hybrid methods for LULC modeling and prediction. Eur. J. Remote Sens. 2018, 51, 251-265. [CrossRef]

9. Ahmed, B.; Ahmed, R. Modeling Urban Land Cover Growth Dynamics Using Multi-Temporal Satellite Images: A Case Study of Dhaka, Bangladesh. ISPRS Int. J. Geo Inf. 2012, 1, 3-31. [CrossRef]

10. Aithal, B.H.; Vinay, S.; Ramachandra, T. V Prediction of Land use Dynamics in the Rapidly Urbanising Landscape using Land Change Modeller. Proc. Int. Conf. Adv. Comput. Sci. AETACS 2013, 1-11.

11. Wu, Q.; Li, H.; Wang, R.; Paulussen, J.; He, Y.; Wang, M.; Wang, B.; Wang, Z. Monitoring and predicting land use change in Beijing using remote sensing and GIS. Landsc. Urban Plan. 2006, 78, 322-333. [CrossRef]

12. Dewan, A.M.; Yamaguchi, Y. Land use and land cover change in Greater Dhaka, Bangladesh: Using remote sensing to promote sustainable urbanization. Appl. Geogr. 2009, 29, 390-401. [CrossRef]

13. Dewan, A.M.; Yamaguchi, Y.; Rahman, M.Z. Dynamics of land use/cover changes and the analysis of landscape fragmentation in Dhaka Metropolitan, Bangladesh. GeoJournal 2012, 77, 315-330. [CrossRef]

14. Guan, D.; Li, H.; Inohae, T.; Su, W.; Nagaie, T.; Hokao, K. Modeling urban land use change by the integration of cellular automaton and Markov model. Ecol. Modell. 2011, 222, 3761-3772. [CrossRef]

15. Rahman, M.T. Detection of Land Use/Land Cover Changes and Urban Sprawl in Al-Khobar, Saudi Arabia: An Analysis of Multi-Temporal Remote Sensing Data. ISPRS Int. J. Geo Inf. 2016, 5, 15. [CrossRef]

16. Kumar, K.S.; Bhaskar, P.U.; Padmakumari, K. Application of Land Change Modeler for Prediction of Future Land Use Land Cover a Case Study of Vijayawada City. Int. J. Adv. Technol. Eng. Sci. 2015, 3, 773-783.

17. Verburg, P.H.; Schot, P.P.; Dijst, M.J.; Veldkamp, A. Land use change modelling: Current practice and research priorities. GeoJournal 2004, 61, 309-324. [CrossRef]

18. Han, H.; Yang, C.; Song, J. Scenario Simulation and the Prediction of Land Use and Land Cover Change in Beijing, China. Sustainability 2015, 7, 4260-4279. [CrossRef]

19. Nourqolipour, R.; Mohamed Shariff, A.R.B.; Balasundram, S.K.; Ahmad, N.B.; Sood, A.M.; Buyong, T.; Amiri, F. A GIS-based model to analyze the spatial and temporal development of oil palm land use in Kuala Langat district, Malaysia. Environ. Earth Sci. 2015, 73, 1687-1700. [CrossRef]

20. Megahed, Y.; Cabral, P.; Silva, J.; Caetano, M. Land Cover Mapping Analysis and Urban Growth Modelling Using Remote Sensing Techniques in Greater Cairo Region-Egypt. ISPRS Int. J. Geo-Information 2015, 4, 1750-1769. [CrossRef]

21. Al-sharif, A.A.A.; Pradhan, B. Monitoring and predicting land use change in Tripoli Metropolitan City using an integrated Markov chain and cellular automata models in GIS. Arab. J. Geosci. 2014, 7, 4291-4301. [CrossRef]

22. Xin, Y.; Xin-qi, Z.; Li-na, L. A spatiotemporal model of land use change based on ant colony optimization, Markov chain and cellular automata. Ecol. Modell. 2012, 233, 11-19.

23. Shivamurthy, V.; Kumar, U. Modelling Urban Revolution in Greater Bangalore, India Modelling Urban Revolution in Greater Bangalore, India. In Proceedings of the 30th Annual In-House Symposium on Space Science and Technology, ISRO-IISc Space Technology Cell, Indian Institute of Science, Bangalore, India, 8 November 2013.

24. Aburas, M.M.; Abdullah, S.H.; Ramli, M.F.; Ash'aari, Z.H.; Ahamad, M.S.S. Simulating and monitoring future land-use trends using CA-Markov and LCM models. In IOP Conference Series: EarthEarth and Environmental Science; IOP Publishing: Bristol, UK, 2018.

25. Brown, D.G.; Walker, R.; Manson, S.; Seto, K. Modeling Land Use and Land Cover Change. In Land Change Science: Observing, Monitoring and Understanding Trajectories of Change on the Earth's Surface; Gutman, G., Janetos, A.C., Justice, C.O., Moran, E.F., Mustard, J.F., Rindfuss, R.R., et al., Eds.; Springer: Dordrecht, The Netherlands, 2004; pp. 395-409. ISBN 978-1-4020-2562-4.

26. Mas, J.-F.; Kolb, M.; Paegelow, M.; Olmedo, M.C.; Houet, T. Modelling Land use/cover changes: A comparison of four software packages. Environ. Model. Software 2014, 51, 94-111. [CrossRef]

27. Council, N.R. Advancing Land Change Modeling: Opportunities and Research Requirement; The National Acedamic Press: Washington, DC, USA, 2014; ISBN 9780309288330.

28. Ansari, A.; Golabi, M.H. Prediction of spatial land use changes based on LCM in a GIS environment for Desert Wetlands-A case study: Meighan Wetland, Iran. Int. Soil Water Conserv. Res. 2019, 7, 64-70. [CrossRef] 
29. Sun, Y. Simulating Future Land Use Change in the East Fork Little Miami River (EFLMR) Watershed in Ohio. Master's Thesis, Nanjing University of Technology, Nanjing, China, 2008.

30. Ozturk, D. Urban Growth Simulation of Atakum (Samsun, Turkey) Using Cellular Automata-Markov Chain and Multi-Layer Perceptron-Markov Chain Models. Remote Sens. 2015, 7, 5918-5950. [CrossRef]

31. Mishra, V.; Rai, P.; Mohan, K. Prediction of land use changes based on land change modeler (LCM) using remote sensing: A case study of Muzaffarpur (Bihar), India. J. Geogr. Inst. Jovan Cvijic SASA 2014, 64, 111-127. [CrossRef]

32. Roy, H.G.; Fox, D.M.; Emsellem, K. Predicting Land Cover Change in a Mediterranean Catchment at Different Time Scales. In Proceedings of the International Conference on Computational Science and Its Applications, Guimaraes, Portugal, 30 June 2014; pp. 315-330.

33. Pérez-Vega, A.; Mas, J.; Ligmann-Zielinska, A. Comparing two approaches to land use/cover change modeling and their implications for the assessment of biodiversity loss in a deciduous tropical forest. Environ. Model. Softw. 2012, 29, 11-23. [CrossRef]

34. Barnsley, M.J.; Barr, S.L.; Swansea, W.; Park, S. Distinguishing Urban Land-Use Categories In Fine Spatial Resolution Land-Cover Data Using A Graph-Based, Structural Pattern Recognition System. Comput. Environ. Urban Syst. 1997, 21, 209-225. [CrossRef]

35. Geoghegan, J.; Wainger, L.A.; Bockstael, N.E. Spatial landscape indices in a hedonic framework: An ecological economics analysis using GIS. Ecol. Econ. 1997, 23, 251-264. [CrossRef]

36. Parker, D.C.; Evans, T.; Meretsky, V.J. Measuring Emergent Properties of Agent-Based Landcover/Landuse Models using Spatial Metrics. In Proceedings of the Seventh Annual Conference of the International Society for Computational Economics, New Haven, CT, USA, 28-29 June 2001.

37. Herold, M.; Goldstein, N.C.; Clarke, K.C. The spatiotemporal form of urban growth: Measurement, analysis and modeling. Remote Sens. Environ. 2003, 86, 286-302. [CrossRef]

38. Jain, S.; Kohli, D.; Rao, R.M. Spatial Metrics to Analyse the Impact of Regional Factors on Pattern of Urbanisation in Gurgaon, India. J. Indian Soc. Remote Sens. 2011, 39, 203-212. [CrossRef]

39. Jia, Y.; Tang, L.; Xu, M.; Yang, X. Landscape pattern indices for evaluating urban spatial morphology-A case study of Chinese cities. Ecol. Indic. 2019, 99, 27-37. [CrossRef]

40. Geri, F.; Rocchini, D.; Chiarucci, A. Landscape metrics and topographical determinants of large-scale forest dynamics in a Mediterranean landscape. Landsc. Urban Plan. 2010, 95, 46-53. [CrossRef]

41. Alberti, M.; Waddell, P. An integrated urban development and ecological simulation model. Integr. Assess. 2000, 1, 215-227. [CrossRef]

42. Liu, J.; Kuang, W.; Zhang, Z.; Xu, X.; Qin, Y.; Ning, J.; Zhou, W.; Zhang, S.; Li, R.; Yan, C.; et al. Spatiotemporal characteristics, patterns, and causes of land-use changes in China since the late 1980s. J. Geogr. Sci. 2014, 24, 195-210. [CrossRef]

43. Hasan, S.; Shi, W.; Zhu, X.; Abbas, S. Monitoring of Land Use/Land Cover and Socioeconomic Changes in South China over the Last Three Decades Using Landsat and Nighttime Light Data. Remote Sens. 2019, 11, 1658. [CrossRef]

44. Braimoh, A.K.; Onishi, T. Spatial determinants of urban land use change in Lagos, Nigeria. Land Use Policy 2007, 24, 502-515. [CrossRef]

45. World Bank. Reducing Inequality for Shared Growth in China Strategy and Policy Options for Guangdong Province; The World Bank: Washington, DC, USA, 2011; ISBN 9780821384848.

46. Hyandye, C.; Martz, L.W. A Markovian and cellular automata land-use change predictive model of the Usangu Catchment. Int. J. Remote Sens. 2017, 38, 64-81. [CrossRef]

47. Li, L.; Wang, Y. Land Use/Cover Change from 2001 to 2010 and its Socioeconomic Determinants in Guangdong Province, A Rapid Urbanization Area of China. J. Agric. Sci. 2015, 86, 275-294.

48. Li, C.; Kuang, Y.; Huang, N.; Zhang, C. The long-term relationship between population growth and vegetation cover: An empirical analysis based on the panel data of 21 cities in Guangdong province, China. Int. J. Environ. Res. Public Health 2013, 10, 660-677. [CrossRef]

49. Ye, Y.; Zhang, J.; Bryan, B.A.; Gao, L.; Qin, Z.; Chen, L.; Yang, J. Impacts of Rapid Urbanization on Ecosystem Services along Urban-Rural Gradients: A Case Study of the Guangzhou-Foshan Metropolitan Area, South China. Ecoscience 2018, 25, 235-247. [CrossRef]

50. 30-Meter SRTM Tile Downloader. Available online: http://dwtkns.com/srtm30m/ (accessed on 30 September 2018). 
51. Open Street Map. Available online: https://download.geofabrik.de/asia.html (accessed on 2 October 2018).

52. Hamdy, O.; Zhao, S.A.; Salheen, M.; Eid, Y.Y. Analyses the Driving Forces for Urban Growth by Using IDRISI ${ }^{\circledR}$ Selva Models Abouelreesh-Aswan as a Case Study. Int. J. Eng. Technol. 2017, 9, 226-232. [CrossRef]

53. Gibson, L.; Münch, Z.; Palmer, A.; Mantel, S. Future land cover change scenarios in South African grasslands-Implications of altered biophysical drivers on land management. Heliyon 2018, 4, e00693. [CrossRef] [PubMed]

54. Dzieszko, P. Land-cover modelling using corine land cover data and multi-layer perceptron. Quaest. Geogr. 2014, 33, 5-22. [CrossRef]

55. Müller, K.; Steinmeier, C.; Küchler, M. Landscape and Urban Planning Urban growth along motorways in Switzerland. Landscape Urban Planning 2010, 98, 3-12. [CrossRef]

56. Reilly, M.K.; Mara, M.P.O.; Seto, K.C. From Bangalore to the Bay Area: Comparing transportation and activity accessibility as drivers of urban growth. Landsc. Urban Plan. 2009, 92, 24-33. [CrossRef]

57. Ye, Y.; Zhang, H.; Liu, K.; Wu, Q. Research on the influence of site factors on the expansion of construction land in the Pearl River Delta, China: By using GIS and remote sensing. Int. J. Appl. Earth Obs. Geoinf. 2013, 21, 366-373. [CrossRef]

58. Maria, A.; Carmelo, A.C.R.; Taniar, D.; Apduhan, B.O.; Hutchison, D. Computational Science and Its Applications-ICCSA 2014; Springer: Cham, Switzerland, 2014; ISBN 9783319091556.

59. Raschio, G.; Alei, F. Methodological Guideline To Produce a Future Deforestation Model for Palm Oil Expansion in Papua New Guinea Using. 2016. Available online: https: //www.undp.org/content/dam/papua_new_guinea/FCPF/ROAR\%20REports/Future\%20Deforestation\% 20Methodological\%20Guidance\%20for\%20PNG.pdf (accessed on 25 July 2019).

60. Ahmed, B. Modelling spatio-temporal urban land cover growth dynamics using remote sensing and GIS techniques: A case study of Khulna City. J. Bangladesh Inst. Planners 2011, 4, 15-32.

61. Eastman, J.R. IDRISI Taiga Guide to GIS and Image Processing (Manual Version 16.02); Clark Labs ClarkUniversity: Worcester, MA, USA, 2009.

62. Falahatkar, S.; Soffianian, A. Integration of Remote Sensing data and GIS for Prediction of Land cover map. Geomatics 2011, 1, 847-864.

63. Wang, R.; Murayama, Y. Change of Land Use/Cover in Tianjin City Based on the Markov and Cellular Automata Models. ISPRS Int. J. Geo Inf. 2017, 6, 150. [CrossRef]

64. Behera, M.D.; Borate, S.N.; Panda, S.N.; Behera, P.R.; Roy, P.S. Modelling and analyzing the watershed dynamics using Cellular Automata (CA)-Markov model-A geo-information based approach. J. Earth Syst. Sci. 2012, 121, 1011-1024. [CrossRef]

65. Omar, N.Q.; Sanusi, S.A.M.; Hussin, W.M.W.; Samat, N.; Mohammed, K.S. Markov-CA model using analytical hierarchy process and multiregression technique. IOP Conf. Ser. Earth Environ. Sci. 2014, 20, 12008. [CrossRef]

66. Chaudhuri, G.; Clarke, K.C. Temporal Accuracy in Urban Growth Forecasting: A Study Using the SLEUTH Model Temporal Accuracy in Urban Growth Forecasting: A Study. Transactions GIS 2014, 18, 302-320. [CrossRef]

67. Martínez, J.Á.; Suárez-seoane, S.; Luis, E. De Landscape and Urban Planning Modelling the risk of land cover change from environmental and socio-economic drivers in heterogeneous and changing landscapes: The role of uncertainty. Landscape Urban Planning 2011, 101, 108-119. [CrossRef]

68. Sahalu, A.G. Analysis of Urban Land Use and Land Cover Changes: A Case Study in Bahir Dar, Ethiopia. Ph.D. Thesis, Westfälische Wilhelms-Universität, Münster, Germany, 2014.

69. Akin, A.; Erdołan, M.A.; Berberołlu, S. The spatiotemporal land use/cover change of Adana city. Int. Arch. Photogramm. Remote Sens. Spat. Inf. Sci. ISPRS Arch. 2013, 40,1-6. [CrossRef]

70. Nichol, J.E.; Abbas, S.; Fischer, G.A. Spatial patterns of degraded tropical forest and biodiversity restoration over 70-years of succession. Glob. Ecol. Conserv. 2017, 11, 134-145. [CrossRef]

71. Herold, M.; Scepan, J.; Clarke, K.C. The use of remote sensing and landscape metrics to describe structures and changes in urban land uses. Environ. Plan. A 2002, 34, 1443-1458. [CrossRef]

72. McGarigal, K.; Cushman, S.A.; Ene, E. FRAGSTATS v4: Spatial Pattern Analysis Program for Categorical and Continuous Maps; University Massachusetts: Amherst, MA, USA, 2012.

73. Reis, J.P.; Silva, E.; Pinho, P. Spatial Metrics to Study Urban Patterns in Growing and Shrinking Cities. Urban Geography 2015, 37, 246-271. [CrossRef] 
74. Fang, X.; Tang, G.; Li, B.; Han, R. Spatial and Temporal Variations of Ecosystem Service Values in Relation to Land Use Pattern in the Loess Plateau of China at Town Scale. PLoS ONE 2014, 9, e110745. [CrossRef]

75. Lombardi, J.V.; Perotto-Baldivieso, H.L.; Tewes, M.E. Land cover trends in South Texas (1987-2050): Potential implications for wild felids. Remote Sens. 2020, 12, 659. [CrossRef]

76. Fragstats Metrics. Available online: http://www.umass.edu/landeco/research/fragstats/documents/Metrics/ Contagion-InterspersionMetrics/FRAGSTATSMetrics.htm (accessed on 12 July 2019).

77. Jack, V.L.; Laack, L.L.; Zimmerman, E.G. Landscape Metrics Associated with Habitat Use by Ocelots in South Texas. J. Wildl. Manag. 2005, 69, 733-738.

78. Perotto-Baldivieso, H.L.; Ben Wu, X.; Peterson, M.J.; Smeins, F.E.; Silvy, N.J.; Wayne Schwertner, T. Flooding-induced landscape changes along dendritic stream networks and implications for wildlife habitat. Landsc. Urban Plan. 2011, 99, 115-122. [CrossRef]

79. Verburg, P.H.; Overmars, K.P. Dynamic Simulation of Land-Use Change Trajectories with the Clue-S Model. In Modelling Land-Use Change: Progress and Applications; Koomen, E., Stillwell, J., Bakema, A., Scholten, H.J., Eds.; Springer Netherlands: Dordrecht, The Netherlands, 2007; pp. 321-337. ISBN 978-1-4020-5648-2.

80. Basse, R.M.; Omrani, H.; Charif, O.; Gerber, P.; Bodis, K. Land use changes modelling using advanced methods: Cellular automata and arti fi cial neural networks. The spatial and explicit representation of land cover dynamics at the cross-border region scale. Appl. Geogr. 2014, 53, 160-171. [CrossRef]

81. Demirel, H.; Sertel, E.; Kaya, S.; Zafer, D. Exploring impacts of road transportation on environment: A spatial approach. Desalination 2008, 226, 279-288. [CrossRef]

82. Rui, Y.; Ban, Y. Urban Growth Modeling with Road Network Expansion and Land Use Development. In Advances in Cartography and GIScience; Ruas, A., Ed.; Springer: Berlin/Heidelberg, Germany, 2011; Volume 2, pp. 399-412.

83. Gülendam, B. Urban Land Use and Land Cover Change Analysis and Modeling. A Case Study Area Malatya, Turkey. Ph.D. Thesis, Westfälische Wilhelms-Universität, Münster, Germany, 2013.

84. Ongsomwang, S.; Pimjai, M. Land Use and Land Cover Prediction and Its Impact On Surface Runoff. Suranaree J. Sci. Technol 2015, 22, 205-223.

85. Hu, Y.; Batunacun; Zhen, L.; Zhuang, D. Assessment of Land-Use and Land-Cover Change in Guangxi, China. Sci. Rep. 2019, 9, 2189. [CrossRef]

86. Poelmans, L.; Van Rompaey, A. Detecting and modelling spatial patterns of urban sprawl in highly fragmented areas: A case study in the Flanders-Brussels region. Landsc. Urban Plan. 2009, 93, 10-19. [CrossRef]

87. Bentai, W.; Chunyu, L. China: Biodiversity Conservation Action Plan. China Environ. Sci. Press. Beijing 1994, 2, 1-50.

88. Klawitter, S. China Case Study:Analysis of National Strategies for Sustainable Development. 2004, pp. 1-7. Available online: https://www.iisd.org/pdf/2004/measure_sdsip_china.pdf (accessed on 15 August 2019).

89. Jia, M.; Wang, Z.; Zhang, Y.; Ren, C.; Song, K. Landsat-Based Estimation of Mangrove Forest Loss and Restoration in Guangxi Province, China, Influenced by Human and Natural Factors. IEEE J. Sel. Top. Appl. Earth Obs. Remote Sens. 2015, 8, 311-323. [CrossRef]

(C) 2020 by the authors. Licensee MDPI, Basel, Switzerland. This article is an open access article distributed under the terms and conditions of the Creative Commons Attribution (CC BY) license (http://creativecommons.org/licenses/by/4.0/). 